\title{
Tiotropium in chronic obstructive pulmonary disease - a review of clinical development
}

\author{
Antonio Anzueto ${ }^{1 *}$ and Marc Miravitlles ${ }^{2}$
}

\begin{abstract}
Background: Bronchodilators are the mainstay of pharmacological treatment in chronic obstructive pulmonary disease (COPD), and long-acting muscarinic antagonist (LAMA) monotherapy is recommended as initial treatment for Global Initiative for Chronic Obstructive Lung Disease (GOLD) groups B, C, and D.

Main body: Tiotropium bromide was the first LAMA available for COPD in clinical practice and, because of its long duration of action, is administered once daily. Tiotropium was initially available as an inhalation powder delivered via a dry-powder inhaler (DPI). Later, tiotropium also became available as an inhalation spray delivered via a soft mist inhaler (SMI). The SMI was designed to overcome or minimize some of the issues associated with other inhaler types (eg, the need for strong inspiratory airflow with DPIs). Results of short- and long-term randomized, controlled clinical trials of tiotropium in patients with COPD indicated tiotropium was safe and significantly improved lung function, health-related quality of life, and exercise endurance, and reduced dyspnea, lung hyperinflation, exacerbations, and use of rescue medication compared with placebo or active comparators. These positive efficacy findings triggered the evaluation of tiotropium in fixed-dose combination with olodaterol (a long-acting $\beta_{2}$-agonist). In this review, we provide an overview of studies of tiotropium for the treatment of COPD, with a focus on pivotal studies.

Conclusion: Tiotropium is safe and efficacious as a long-term, once-daily LAMA for the maintenance treatment of COPD and for reducing COPD exacerbations. The SMI generates a low-velocity, long-duration aerosol spray with a high fine-particle fraction, which results in marked lung drug deposition. In addition, high inspiratory flow rates are not required.

Keywords: Chronic obstructive pulmonary disease, Dry-powder inhaler, Dyspnea, Exacerbations, HandiHaler, Longacting muscarinic antagonist, Lung function, Respimat ${ }^{\oplus}$, Soft mist inhaler, Tiotropium

An accompanying infographic is provided as Additional file 1.
\end{abstract}

\section{Background}

Bronchodilators are the mainstay of pharmacological treatment in chronic obstructive pulmonary disease (COPD) [1]. The 2020 update of the Global Initiative for Chronic Obstructive Lung Disease (GOLD) strategy

\footnotetext{
*Correspondence: anzueto@uthscsa.edu

'Internal Medicine, Pulmonary Disease, University of Texas Health, and South Texas Veterans Health Care System, San Antonio, TX, USA

Full list of author information is available at the end of the article
}

document includes a model for initiation of pharmacological treatment, which is based on assessment of symptoms and exacerbation risk according to the $\mathrm{ABCD}$ assessment tool [2]. After initial treatment, the GOLD committee recommends regular review of symptoms; assessment of inhaler technique and adherence, as well as non-pharmacological approaches; and treatment adjustment as needed. A separate follow-up treatment algorithm is provided that is based on the predominant 
treatable trait (dyspnea or exacerbations) and current treatment, and is independent of $\mathrm{ABCD}$ group at initiation of treatment [2]. Long-acting muscarinic antagonist (LAMA) monotherapy is recommended as initial treatment for GOLD groups $\mathrm{B}, \mathrm{C}$, and D [2]. Alternatively, long-acting $\beta_{2}$-agonist (LABA) monotherapy can be used as initial treatment for GOLD group $B$, and dual bronchodilator therapy with a LABA/LAMA combination may be considered for group $B$ patients with severe breathlessness. Dual bronchodilator therapy also is an initial treatment option for group D patients who are highly symptomatic (COPD Assessment Test [CAT] score > 20), and a combination of a LABA and inhaled corticosteroid (ICS) is an initial treatment option for group D patients with a blood eosinophil count of 300 cells $/ \mu \mathrm{L}$ or more. In general, ICS-based therapy recommendations are guided by exacerbation history, blood eosinophil counts, and coexistent asthma in the GOLD 2020 update [2].

LAMAs inhibit the bronchoconstrictor effect of acetylcholine by prolonged binding to the M3 muscarinic receptors present on airway smooth muscles and faster dissociation from M2 receptors [2, 3]. Tiotropium bromide, the first LAMA available for COPD in clinical practice, with a dissociation half-life of $35 \mathrm{~h}$ from the M3 receptor, is structurally related to ipratropium $[4,5]$. Ipratropium has a short duration of action, with a dissociation half-life of $0.3 \mathrm{~h}$ from the M3 receptor and requires four-times-a-day (QID) dosing, potentially affecting adherence to therapy $[4,5]$. In contrast, tiotropium has a long duration of action, enabling once-daily (QD) dosing [5]. Tiotropium was first available as an inhalation powder delivered via a dry-powder inhaler (DPI; Spiriva ${ }^{\circ}$ HandiHaler; ; Boehringer Ingelheim Pharmaceuticals, Inc) and later became available as an inhalation spray delivered via a soft mist inhaler (SMI; Spiriva ${ }^{\circ}$ Respimat ${ }^{\circ}$; Boehringer Ingelheim Pharmaceuticals, Inc). Tiotropium HandiHaler ${ }^{\circ}$ and tiotropium Respimat ${ }^{\circ}$ are indicated for long-term, QD maintenance treatment of bronchospasm associated with COPD and for reducing COPD exacerbations in the United States (US), European Union (EU), and other countries [6, 7]. A LABA/ LAMA combination is used to leverage their different mechanisms of action. While LAMAs prevent bronchoconstriction, LABAs relax bronchial smooth muscle and cause bronchodilation by stimulating $\beta 2$-adrenergic receptors in airway smooth muscle which trigger cellular pathways [8]. Tiotropium in a fixed-dose combination with the LABA olodaterol (Stiolto ${ }^{\circ}$ Respimat $^{\circ}$ inhalation spray [Spiolto ${ }^{\circ}$ Respimat $^{\circ}$ inhalation solution in Europe]; Boehringer Ingelheim Pharmaceuticals, Inc) is indicated for the long-term, QD maintenance treatment of patients with COPD $[9,10]$.

DPIs, pressurized metered-dose inhalers (pMDIs), and SMIs are used for delivery of inhaled COPD medications. However, patients with COPD might not be able to generate the inspiratory flow necessary for optimal drug de-aggregation and lung deposition with DPIs [11]. DPIs with varying internal resistances are available [11], and patients' peak inspiratory flow should ideally be assessed before prescribing a DPI [12]. Further, the velocity of the aerosol from pMDIs and the inability of some patients with COPD to properly coordinate actuation and inhalation when using pMDIs can lead to considerable oropharyngeal drug deposition [11]. Use of a spacer or holding chamber with a pMDI helps slow the velocity of aerosolized particles; removes larger, nonrespirable particles; and reduces oropharyngeal deposition [13]. Respimat ${ }^{\circ}$, the only available SMI, is a propellantfree inhaler that uses mechanical energy to generate a fine, slow-moving mist [14]. Respimat ${ }^{\oplus}$ provides a higher lung drug deposition than pMDIs or DPIs [15-17], delivers the dose of medication independent of the patient's inspiratory effort [18], and requires minimal coordinated actuation and inhalation $[19,20]$, thereby making it suitable for a range of patients with COPD [14].

Cumulative results of clinical trials indicate that tiotropium significantly improves lung function (vs placebo [21-33], ipratropium [27, 34], or salmeterol [35, 36]), reduces dyspnea (vs placebo [22, 28], salmeterol [35], or ipratropium [34]), reduces exacerbations (vs placebo [22-24, 26, 28, 36-38], ipratropium [34], or salmeterol [39]), and improves health-related quality of life (HRQoL; vs placebo [22, 23, 26, 28, 29, 32, 35, 36] or ipratropium [34]; Fig. 1). As reviewed here, most of the evidence base for use of tiotropium in COPD was derived from studies of the initial dry powder formulation. Results of studies of tiotropium as an inhalation solution delivered via an SMI confirmed its long-term efficacy benefits and safety profile. The clinical development of tiotropium in COPD culminated with evidence supporting its use in fixed-dose combination with olodaterol. The objective of this review is to comprehensively detail the key clinical trial evidence for use of tiotropium monotherapy in COPD.

\section{Initial studies with tiotropium inhalation powder Dose response and comparison with ipratropium}

In a 4-week, dose-response study of tiotropium inhalation powder $(4.5,9,18$, and $36 \mu \mathrm{g}$ QD) in patients with COPD $(n=169)$, all doses significantly improved lung function compared with placebo (day 29; difference in trough forced expiratory volume in $1 \mathrm{~s}\left[\mathrm{FEV}_{1}\right]$ response $=$ $0.14 \mathrm{~L}, 0.11 \mathrm{~L}, 0.15 \mathrm{~L}$, and $0.19 \mathrm{~L}$, respectively; $p<0.05$ for all) [31]. Similarly, forced vital capacity (FVC) was higher for all doses of tiotropium than with placebo (day 29; difference in trough $\mathrm{FVC}$ response $=0.31 \mathrm{~L}, 0.22 \mathrm{~L}$, $0.37 \mathrm{~L}$, and $0.22 \mathrm{~L}$, respectively; $p<0.05$ for $4.5-\mu \mathrm{g}$ and 18.0- $\mu \mathrm{g}$ doses). All tiotropium doses also increased peak 


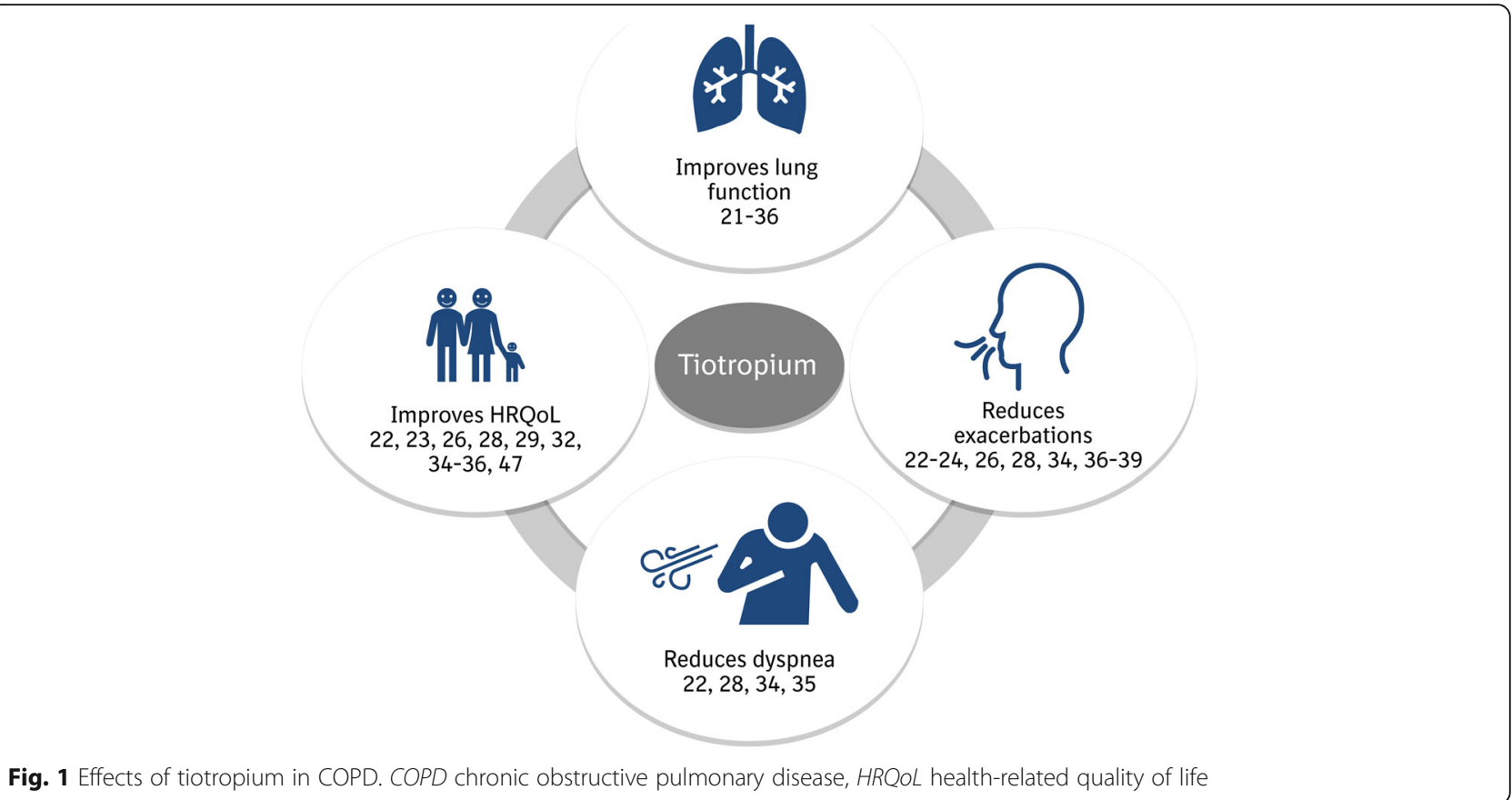

Fig. 1 Effects of tiotropium in COPD. COPD chronic obstructive pulmonary disease, HRQoL health-related quality of life

expiratory flow rate (PEFR) compared with placebo at all test points (morning, noon, and evening) [31]. Improvement in lung function was maintained throughout the treatment period. The overall safety profile of the four tiotropium doses was similar to that of placebo [31]. Based on these results, a dosage of $18 \mu \mathrm{g}$ QD was evaluated in a 3-month, randomized controlled trial (RCT; $\mathrm{n}=470$ ) [21]. Again, tiotropium significantly improved lung function compared with placebo (day 92; difference in trough $\mathrm{FEV}_{1}$ response $=0.15 \mathrm{~L}$; difference in trough $\mathrm{FVC}$ response $=0.28 \mathrm{~L} ; p<0.001$ for both), and improvements were maintained throughout the treatment period. Tiotropium also significantly improved daily morning and evening PEFR and reduced symptoms of wheezing, shortness of breath, and "as-needed" albuterol use. Safety of tiotropium was similar to that of placebo, except for dry mouth, which was more common with tiotropium than with placebo $(9.3 \%$ vs $1.6 \% ; p<0.05)$ [21]. Further, the efficacy and safety of tiotropium $18 \mu \mathrm{g}$ QD was compared with that of ipratropium $40 \mu \mathrm{g}$ QID (via a pMDI) in a 13 -week study $(\mathrm{n}=288)$ [40]. Tiotropium improved lung function compared with ipratropium throughout the treatment period (day 92; mean difference in trough $\mathrm{FEV}_{1}$ response $=0.13 \mathrm{~L}[p=0.0001]$; mean difference in trough $\mathrm{FVC}$ response $=0.21 \mathrm{~L}[p=$ $0.0003])$. Tiotropium also consistently improved weekly mean morning and evening PEFR and reduced the use of rescue salbutamol. As observed in other studies, dry mouth was more common with tiotropium than with ipratropium (14.7\% vs 10.3\%) [40].

\section{Pivotal trials}

In a 6-month RCT $(n=623)$, tiotropium $18 \mu \mathrm{g}$ QD compared with the LABA salmeterol $50 \mu \mathrm{g}$ twice daily (BID; delivered via a pMDI) significantly improved lung function (week 24; difference in trough $\mathrm{FEV}_{1}$ response = $0.052 \mathrm{~L}$; difference in trough $F V C$ response $=0.112 \mathrm{~L}$; $p<0.01$ for both) and reduced dyspnea (week 24; difference in transition dyspnea index [TDI] focal score = $0.78 \mathrm{U} ; p<0.05)$ [35]. Both active drugs significantly reduced the need for rescue albuterol compared with placebo $(p<0.0001)$. In this study, tiotropium also significantly improved HRQoL compared with placebo (week 24; difference in St. George's Respiratory Questionnaire [SGRQ] total score $=-2.71 \mathrm{U} ; p<0.05)$ but not salmeterol (difference $=-1.6 \mathrm{U} ; p>0.05$ ). Safety of tiotropium was similar to that of placebo and salmeterol, except for dry mouth, which was more common with tiotropium (10\%) [35]. Health outcomes were evaluated in two 6-month RCTs $(\mathrm{n}=1207)$ in which tiotropium $18 \mu \mathrm{g}$ compared with placebo significantly reduced the number of exacerbations/patient-year (PY; 1.07 vs 1.49; $p<0.05)$, increased the time to first exacerbation $(p \leq$ 0.01 ), and improved HRQoL (difference in SGRQ total score $=-2.7 \mathrm{U} ; p<0.01$ ) during the treatment period [36]. Salmeterol did not significantly differ from placebo for these outcomes. Although both active drugs improved lung function, tiotropium did so to a greater extent than salmeterol. Dry mouth was more common with tiotropium $(8.2 \%)$ than with salmeterol $(1.7 \%)$ or placebo $(2.3 \%)$ [36]. 
In two identical 12-month RCTs $(\mathrm{n}=921)$, tiotropium $18 \mu \mathrm{g}$ QD significantly improved lung function compared with placebo (difference in trough $\mathrm{FEV}_{1}$ response $=0.12-0.15 \mathrm{~L}$ [range over days $1-344$ ]; $p<0.01$ ) [22]. In addition, compared with patients who received placebo, those who received tiotropium also had significantly less dyspnea (difference in TDI focal score $=0.8$ $1.1 \mathrm{U}$ [range over days 50-344]; $p<0.001$ ), better health status scores $(p<0.05)$, and fewer COPD exacerbations/ PY (0.76 vs $0.95 ; p=0.045)$ and exacerbation-related hospitalizations $(p<0.05)$. In this and other tiotropium trials, patients were allowed to continue taking glucocorticoids during the study period. As observed in prior studies, incidence of dry mouth was higher with tiotropium than with placebo $(16.0 \%$ vs $2.7 \% ; p<0.05)$. In two other identical 12-month RCTs $(\mathrm{n}=535)$, tiotropium $18 \mu \mathrm{g}$ QD compared with ipratropium $40 \mu \mathrm{g}$ QID (delivered via a pMDI) significantly improved lung function (difference in trough $\mathrm{FEV}_{1}$ response $=0.15 \mathrm{~L} ; p<0.001$ ) and reduced the use of rescue salbutamol $(p<0.05)$ at the end of the treatment period [34]. In addition, tiotropium compared with ipratropium significantly reduced dyspnea (day 364; difference in TDI focal score $=0.90 \mathrm{U}$; $p=0.001)$ and the number of exacerbations/PY (0.73 vs 0.96; $p=0.006$ ); improved PEFR (difference in morning PEFR $=10-18 \mathrm{~L} / \mathrm{min}$ [range over days $1-365$ ]; difference in evening PEFR $=9-18 \mathrm{~L} / \mathrm{min}$ [range over days $1-365$ ]; $p<0.01$ ) and HRQoL (day 364; difference in SGRQ total score $=-3.30 ; p=0.004)$; and increased the time to first exacerbation $(p=0.008)$ and time to first exacerbationrelated hospitalization $(p=0.048)$. These improvements were maintained throughout the treatment period. Collectively, results of these studies showed that QD tiotropium $18 \mu \mathrm{g}$ was a safe and efficacious LAMA for maintenance treatment of COPD and for reducing exacerbations, leading to the approval of Spiriva ${ }^{\circ}$ HandiHaler ${ }^{\circledR}$ in the EU (2002), US (2004), and other countries $[41,42]$.

\section{Effect on lung hyperinflation, exercise endurance, exertional dyspnea, and $\mathrm{HRQ} \mathrm{oL}$}

Patients with COPD often experience hyperinflation, which results in reduced inspiratory capacity (IC), limited exercise capacity, and increased exertional dyspnea $[2,43]$. A few RCTs were designed to specifically evaluate the effects of tiotropium on these parameters.

In a 4-week RCT $(\mathrm{n}=81)$, tiotropium $18 \mu \mathrm{g}$ QD significantly improved lung function and IC compared with placebo (mean differences at week 4: trough $\mathrm{FEV}_{1}=$ $0.16 \mathrm{~L}$; trough $\mathrm{FVC}=0.33 \mathrm{~L}$; trough $\mathrm{IC}=0.22 \mathrm{~L} ; p<0.01$ for all) [44]. Similarly, in a 6-week RCT $(n=187)$, tiotropium significantly improved lung function compared with placebo, consistent with findings from prior studies [45]. Further, tiotropium compared with placebo significantly reduced lung hyperinflation (residual volume, $p<0.001$; functional residual capacity, $p<0.001$ ); increased vital capacity $(p<0.0001)$, IC (difference in trough response $=0.10 \mathrm{~L} ; p<0.05$ ), and exercise endurance (difference in endurance time $=105 \mathrm{~s}[21 \%] ; p<$ $0.01)$; and decreased exertional dyspnea $(p<0.01)$ on day 42 [45]. Change from baseline in all parameters was evident after the first treatment and persisted for the duration of the trial. In a subsequent 6-week study $(\mathrm{n}=$ 261), effects of tiotropium on lung hyperinflation, symptom-limited exercise tolerance, and exertional dyspnea were apparent at $2.25 \mathrm{~h}$ of treatment and lasted for $8 \mathrm{~h}$ after dosing on day 42 [46]. These findings were corroborated by results of another RCT $(n=100)$, where tiotropium $18 \mu \mathrm{g}$ compared with placebo not only significantly improved trough FVC (difference $=0.20 \mathrm{~L} ; p<$ 0.05 ) and trough IC (difference $=0.15 \mathrm{~L} ; p<0.05$ ) but also significantly increased mean distance walked during the shuttle-walk test (difference $=36 \mathrm{~m} ; p<0.05$ ) and improved HRQoL (difference in SGRQ total score = $6.5 ; p=0.026)$ after 12 weeks of treatment [32]. Further, in an RCT $(\mathrm{n}=554)$ by the Tiotropium: Influence sur la Perception de l'amélioration des activites Habituelles Objectivée par une echelle Numerique (TIPHON) group-in addition to significantly improving lung function (difference in trough $\mathrm{FEV}_{1}=0.10 \mathrm{~L} ; p=0.0001$ ) and reducing exacerbations/PY (1.05 vs $1.83 ; p=0.0287$ ) tiotropium compared with placebo significantly increased the proportion of patients achieving clinically relevant improvement in HRQoL (difference in responders $=10.9 \% ; p=0.029$ ) after 9 months of treatment [23]. In contrast to the results of the above studies, in a 96-week RCT $(\mathrm{n}=519)$, the difference in endurance time between tiotropium $18 \mu \mathrm{g}$ QD and placebo was not statistically significant (tiotropium/placebo $=1.13 ; 95 \% \mathrm{CI}=$ $0.97-1.32 ; p=0.106$ ). However, consistent with previous studies, tiotropium improved HRQoL at 96 weeks compared with placebo (difference in SGRQ total score = $4.03 \mathrm{U} ; p=0.007$ ) [47].

\section{Effect on exacerbations}

Patients with COPD, even those with mild disease, can experience exacerbations [48-51], which account for a large proportion of total COPD burden on the healthcare system [52, 53]. Recommendations for reducing COPD exacerbations and treatment of stable COPD have been provided by GOLD [2], the European Respiratory Society/American Thoracic Society [54], and the Spanish Society of Pulmonology and Thoracic Surgery $[55,56]$. The efficacy of tiotropium $18 \mu \mathrm{g}$ QD in reducing exacerbations was evaluated in several short- and long-term studies, including those mentioned above (Table 1; summarized by Anzueto et al. [57]). 
Table 1 Tiotropium reduces exacerbation and increases time to first exacerbation

\begin{tabular}{|c|c|c|c|c|c|c|}
\hline Study & Comparator & $\begin{array}{l}\text { Patients } \\
\text { (N) }\end{array}$ & $\begin{array}{l}\text { Study } \\
\text { duration }\end{array}$ & $\begin{array}{l}\text { Change from baseline in number } \\
\text { of exacerbations }\end{array}$ & $\begin{array}{l}\text { Change from baseline in patients } \\
\text { with } \geq 1 \text { exacerbation }\end{array}$ & $\begin{array}{l}\text { Increase in time to first } \\
\text { exacerbation }\end{array}$ \\
\hline $\begin{array}{l}\text { Casaburi } 2002 \\
{[22]}\end{array}$ & Placebo & 921 & 1 year & $-20 \%(p=0.045)$ & $-14 \%(p<0.05)$ & $p=0.011$ \\
\hline $\begin{array}{l}\text { Vincken } 2002 \\
\text { [34] }\end{array}$ & Ipratropium & 535 & 1 year & $-24 \%(p=0.006)$ & $-24 \%(p=0.014)$ & $p=0.008$ \\
\hline $\begin{array}{l}\text { Brusasco } 2003 \\
{[36]}\end{array}$ & Placebo & $802^{\mathrm{a}}$ & 6 months & $-28 \%(p<0.05)$ & $-18 \%(p>0.05)$ & $p \leq 0.01$ \\
\hline $\begin{array}{l}\text { Niewoehner } \\
2005 \text { [37] }\end{array}$ & Placebo & 1829 & 6 months & $-19 \%(p=0.031)$ & $-14 \%(p=0.037)$ & $p=0.028$ \\
\hline $\begin{array}{l}\text { Dusser } 2006 \\
{[24]}\end{array}$ & Placebo & 1010 & 1 year & $-35 \%(p<0.001)$ & $-17 \%(p<0.01)$ & $p<0.001$ \\
\hline $\begin{array}{l}\text { Tashkin } 2008 \\
\text { [26] }\end{array}$ & Placebo & 5993 & 4 years & $-14 \%(p<0.001)$ & $-2 \%(p=0.35)$ & $p<0.001$ \\
\hline $\begin{array}{l}\text { Tonnel } 2008 \\
{[23]}\end{array}$ & Placebo & 554 & 9 months & $-43 \%(p=0.0287)$ & $-16 \%(p=0.1013)$ & $p=0.0081$ \\
\hline $\begin{array}{l}\text { Bateman } 2010 \\
{[28]}\end{array}$ & Placebo & 1990 & 1 year & $p<0.01^{* *}$ & $-16 \%(p<0.01)^{b}$ & $p<0.0001^{b}$ \\
\hline $\begin{array}{l}\text { Bateman } 2010 \\
\text { [29] }\end{array}$ & Placebo & 3991 & 48 weeks & $-21 \%(p<0.0001)$ & $-18 \%(p<0.0001)$ & $p<0.0001$ \\
\hline $\begin{array}{l}\text { Vogelmeier } \\
2011[39]\end{array}$ & Salmeterol & 7376 & 1 year & $-11 \%(p=0.002)^{c}$ & $-11 \%(p<0.001)^{c}$ & $p<0.001$ \\
\hline
\end{tabular}

${ }^{* *} p<0.01$ for tiotropium $5 \mu \mathrm{g}$ dose and $p<0.001$ for tiotropium $10 \mu \mathrm{g}$ dose

${ }^{\mathrm{a}}$ This number does not include the patients in the salmeterol group. ${ }^{\mathrm{b}}$ For both tiotropium $5-\mu \mathrm{g}$ and $10-\mu \mathrm{g}$ doses. ${ }^{\mathrm{c}}$ Refers to moderate or severe exacerbations

In an RCT $(\mathrm{n}=1829)$ conducted in a US Veterans Affairs setting, fewer patients treated with tiotropium than placebo experienced $\geq 1$ exacerbation (difference $=-$ $5.7 \% ; p=0.037$ ) or exacerbation-related hospitalization (difference $=-3.0 \% ; p=0.056$ ) after 6 months of treatment [37]. Analysis of secondary outcomes indicated that tiotropium significantly increased time to first exacerbation $(p=0.028)$ and reduced health care resource utilization (HCRU; frequency of hospitalizations, $p=$ 0.047; antibiotic treatment days, $p=0.015$; and unscheduled clinic visits, $p=0.019)$. Similar results were observed in another RCT ( $\mathrm{n}=1010$; Mesure de l'Influence de Spiriva ${ }^{\circ}$ sur les Troubles Respiratoires Aigus à Long terme [MISTRAL]) [24], where tiotropium compared with placebo significantly increased time to first exacerbation $(p<0.001)$ and reduced the number of exacerbations/PY (1.57 vs $2.41 ; p<0.001)$, proportion of patients with $\geq 1$ exacerbation (difference $=-10.4 \% ; p<0.01$ ), and HCRU (concomitant respiratory medications, $p<0.0001$; antibiotics, $p<0.001$; and oral steroids, $p<0.01$; and the number of unscheduled physician contacts, $p<0.05$ ) after treatment for 1 year [24]. Tiotropium also significantly improved weekly morning PEFR (mean difference over 1 year $=25 \mathrm{~L} / \mathrm{min} ; p<0.0001$ ), trough $\mathrm{FEV}_{1}$ (mean difference $=0.12 \mathrm{~L} ; p<0.0001$ ), FVC (mean difference $=$ $0.17 \mathrm{~L} ; p<0.0001$ ), and IC (mean difference $=0.14 \mathrm{~L} ; p<$ 0.001 ) at the end of the treatment period. As observed in other studies, the safety of tiotropium was similar to that of placebo, except for dry mouth, which was more frequent with tiotropium (4.0\%) than with placebo (1.4\%) [24]. In addition, in the Prevention Of Exacerbations with Tiotropium in COPD (POET-COPD) trial $(\mathrm{n}=7376)$, tiotropium $18 \mu \mathrm{g}$ QD was significantly more efficacious than salmeterol $50 \mu \mathrm{g}$ BID in increasing the time to first exacerbation (hazard ratio $[\mathrm{HR}]=0.83$ [ie, $17 \%$ reduction in risk of exacerbations with tiotropium]; $p<0.001)$ and reducing the annual rate of moderate or severe exacerbations ( 0.64 vs 0.72 ; rate ratio $[R R]=0.89$ [11\% reduction with tiotropium]; $p=0.002$ ) and severe exacerbations ( 0.09 vs 0.13 ; $\mathrm{RR}=0.73$ [ie, $27 \%$ reduction with tiotropium]; $p<0.001$ ) after 1 year of treatment [39]. The safety of tiotropium was similar to that of salmeterol. In a post hoc analysis of POET-COPD, tiotropium compared with salmeterol increased the time to first exacerbation and reduced the number of exacerbations in patients at low and high risk of exacerbation (time to first exacerbation: $\mathrm{HR}=0.89 ; p=0.1046$ and $\mathrm{HR}=0.84 ; p=0.0002$, respectively; number of exacerbations: $\mathrm{RR}=0.89 ; p=0.1768$ and $\mathrm{RR}=0.90 ; p=0.0383$, respectively) [58].

\section{Longer-term studies}

Longer-term studies were designed to expand upon findings from the 6- and 12-month RCTs. In a 2-year RCT $(n=841)$ of patients with early-stage COPD (ie, GOLD stage 1 [mild] or 2 [moderate]) in China, tiotropium HandiHaler $18 \mu \mathrm{g}$ QD compared with placebo significantly improved lung function throughout the 2-year 
period (range of mean differences in $\mathrm{FEV}_{1}$ : before bronchodilator use $=0.127-0.169 \mathrm{~L} ;$ after bronchodilator use $=0.071-0.133 \mathrm{~L} ; p<0.001$ for both) [25]. In addition, in the Understanding Potential Long-Term Impacts on Function with Tiotropium (UPLIFT) trial $(\mathrm{n}=5993)$, tiotropium compared with placebo significantly improved lung function (range of mean differences in $\mathrm{FEV}_{1}$ : before bronchodilator use $=0.087-0.103 \mathrm{~L}$; after bronchodilator use $=0.047-0.065 \mathrm{~L} ; p<0.001$ for both), reduced the number of exacerbations $/ \mathrm{PY}$ ( 0.73 vs 0.85 ; relative risk $=$ 0.86 [ie, $14 \%$ reduction with tiotropium]; $p<0.001$ ), increased the time to first exacerbation $(p<0.001)$, improved HRQoL (mean difference in SGRQ total score = $-2.7 \mathrm{U} ; p<0.001)$, and reduced mortality $(\mathrm{HR}=0.87$; $95 \%$ confidence interval $[\mathrm{CI}]=0.76-0.99$ ) in patients with moderate-to-very severe COPD treated for 4 years [26]. Tiotropium significantly improved $\mathrm{FEV}_{1}$ and HRQoL compared with placebo throughout the trial.

Conflicting results were reported, however, with respect to the effect of tiotropium on annual decline in $\mathrm{FEV}_{1}$. Tiotropium compared with placebo significantly reduced the annual decline in $\mathrm{FEV}_{1}$ after bronchodilator use in the aforementioned 2-year RCT in China [25] (mean decline in $\mathrm{FEV}_{1}$ from day 30 to month 24: before bronchodilator use $=0.038 \mathrm{~L} /$ year vs $0.053 \mathrm{~L} /$ year $[p=$ 0.06]; after bronchodilator use $=0.029 \mathrm{~L} /$ year vs $0.051 \mathrm{~L} /$ year $[p=0.006])$ and in a retrospective analysis of two 1year RCTs (mean decline in trough $\mathrm{FEV}_{1}$ from days 8 to $344=0.012$ vs $0.058 \mathrm{~L} /$ year; $p=0.005$ ) [59]. In UPLIFT, however, the annual decline in $\mathrm{FEV}_{1}$ was not significantly different between the tiotropium and placebo groups (mean decline in $\mathrm{FEV}_{1}$ from day 30 to month 48: before bronchodilator use $=0.030 \mathrm{~L} /$ year vs $0.030 \mathrm{~L} /$ year $[p=0.95]$; after bronchodilator use $=0.040 \mathrm{~L} /$ year vs $0.042 \mathrm{~L} /$ year $[p=0.21]$ ) [26]. In a pre-specified subgroup analysis of the UPLIFT trial in patients with GOLD stage II COPD, the annual decline in post-bronchodilator $\mathrm{FEV}_{1}$ was lower in the tiotropium group compared with the placebo group (mean decline in post-bronchodilator $\mathrm{FEV}_{1}$ from day 30 to month 48: $0.043 \mathrm{~L} /$ year vs $0.049 \mathrm{~L} /$ year $[p=0.024]$ ), supporting benefits of early intervention in COPD [60].

Long-term effects of tiotropium as first-line maintenance medication in COPD were further evaluated in a secondary analysis of data from the UPLIFT trial [61]. In addition, various post hoc and subgroup analyses were conducted to assess the long-term efficacy of 4 years of treatment with tiotropium with regard to smoking status [62], sex [63], and baseline $\mathrm{FEV}_{1} \geq 60 \%$ predicted [64]. In the latter analysis $(\mathrm{n}=1210)$, tiotropium compared with placebo significantly improved lung function (difference in pre-bronchodilator $\mathrm{FEV}_{1}=0.087-0.127 \mathrm{~L}$ [range over months 1-48]; difference in post-bronchodilator $\mathrm{FEV}_{1}=0.038-0.084 \mathrm{~L}$ [range over months 1-48]; $p \leq 0.002$ for both) and HRQoL (difference in SGRQ total score $=-2.0$ to $-3.4 \mathrm{U} ; p<0.05)$ and reduced the risk of exacerbations ( $\mathrm{HR}=0.83$; $95 \% \mathrm{CI}=0.71-$ $0.96)$ and mortality $(\mathrm{HR}=0.66 ; 95 \% \mathrm{CI}=0.45-0.96)$ over the 4-year treatment period [64]. In another analysis of the UPLIFT data, patients taking ICS had significantly higher incidence rates of pneumonia (0.068 vs $0.056 ; p=0.012)$ and COPD exacerbations $(0.88$ vs $0.62 ; p<0.001)$ than patients not taking ICS [65]. An attenuated rate of pneumonia was observed in the tiotropium subgroup, in general, irrespective of ICS use (pneumonia incidence rate: fluticasone $/$ placebo $=0.081$; fluticasone $/$ tiotropium $=0.073$; other $\mathrm{ICS} /$ placebo $=0.062$; other ICS/tiotropium $=0.055$; no ICS $/$ placebo $=0.055$; and no ICS/tiotropium $=0.056$ ), suggesting the adverse effects associated with the use of ICS might be mitigated with add-on tiotropium.

\section{Efficacy and safety vs other therapies Tiotropium vs ICS/LABA}

Tiotropium $18 \mu \mathrm{g}$ QD provided a bronchodilatory effect comparable to fluticasone/salmeterol 250/50 $\mu \mathrm{g}$ BID in a 6-week RCT $(n=107)$ of patients with moderate-to-very severe COPD [66]. In addition, in the Investigating New Standards for Prophylaxis in Reducing Exacerbations (INSPIRE) trial $(\mathrm{n}=1323)$, fluticasone/salmeterol $500 / 50 \mu \mathrm{g}$ BID was comparable to tiotropium $18 \mu \mathrm{g}$ QD in reducing exacerbations (modeled annual exacerbation rate $=1.28$ vs 1.32; $p=0.656)$ in patients with severe and very severe COPD after 2 years of treatment [67]. However, fluticasone/salmeterol was associated with an increased incidence of pneumonia compared with tiotropium $(p=0.008)$ [67].

\section{Tiotropium vs short-acting muscarinic antagonist/short- acting $\beta_{2}$-agonist (SAMA/SABA) combinations}

Patients with moderate-to-very severe COPD taking ipratropium/albuterol 36/206 $\mu \mathrm{g}$ QID delivered via a pMDI who switched to tiotropium $18 \mu \mathrm{g}$ QD had significantly improved lung function compared with those who continued taking ipratropium/albuterol (difference in mean trough $\mathrm{FEV}_{1}$ at 84 days $=0.086 \mathrm{~L} ; p<0.0001$ ) in a randomized, parallel-group, double-blind, doubledummy study $(n=676)$ [68]. The incidence of respiratory adverse events was lower in the tiotropium group than in the ipratropium/albuterol group [68]. Additionally, tiotropium significantly reduced the risk of exacerbations $(p=0.0086)$ and COPD-related referrals/ hospitalizations $(p=0.004)$ compared with ipratropium/ salbutamol at the end of treatment in a retrospective, 12-month, follow-up study $(\mathrm{n}=4193)$ using the United Kingdom General Practice Research Database [69].

\section{Tiotropium vs QD LABA}

The efficacy of QD indacaterol was compared with that of QD tiotropium in several trials. Indacaterol $150 \mu \mathrm{g}$ QD and indacaterol $300 \mu \mathrm{g}$ QD delivered via a DPI (Onbrez 
Breezhaler; Novartis Pharmaceuticals) were at least as effective as tiotropium $18 \mu \mathrm{g}$ QD in improving lung function and clinical outcomes in patients with moderate-to-severe COPD in short-term trials: INdacaterol \& TIotropium: Measuring Efficacy (INTIME; indacaterol 150 or $300 \mu \mathrm{g}$; 14 days, $\mathrm{n}=169$ ) [70], INdacaterol Towards Establishment of cliNical SuperiorITY study (INTENSITY; indacaterol $150 \mu \mathrm{g} ; 12$ weeks, $\mathrm{n}=1598$ ) [71], and Indacaterol to Help Achieve New COPD treatment Excellence (INHANCE; indacaterol 150 or $300 \mu$; 26 weeks, $n=1683$ ) [72]. Further, indacaterol $150 \mu \mathrm{g}$ QD was non-inferior to tiotropium $18 \mu \mathrm{g}$ QD in improving lung function (week 12; least squares mean difference in trough $\mathrm{FEV}_{1}=-0.011 \mathrm{~L} ; p<$ 0.0001 ) in patients with severe COPD and a history of $\geq 1$ exacerbation in the previous year in the 52-week Indacaterol: Providing Opportunity to Re-engage Patients with Life (INVIGORATE) trial $(\mathrm{n}=3444)$ [73]. Tiotropium was superior to indacaterol in reducing exacerbations (week 52 ; annual rate $=0.73$ vs $0.90 ; p<0.001$ ). Safety was similar between the treatment groups.

\section{Tiotropium vs other LAMAs}

In a 6-week RCT $(n=414)$, the efficacy of aclidinium $400 \mu \mathrm{g}$ BID delivered via a DPI (Genuair $/$ Pressair $^{\mathrm{rm}}$; AstraZeneca) was compared with that of placebo and tiotropium $18 \mu \mathrm{g}$ QD in patients with moderate-to-severe COPD [74]. Both aclidinium and tiotropium compared with placebo significantly improved lung function (differences in change from baseline in $\mathrm{FEV}_{1}$ area under the curve for the 24- $\mathrm{h}$ period post-morning dose $\left[\mathrm{AUC}_{0-24}\right]=0.15 \mathrm{~L}$ and $0.14 \mathrm{~L}$, respectively; both $p<0.0001)$ and COPD symptom scores ( $p<0.0001$ and $p<0.05$, respectively) at the end of the treatment period. Aclidinium, but not tiotropium, reduced the severity of nighttime symptoms vs placebo $(p<0.05)$. Safety was similar between treatment groups. At week 12 of the glycopyrronium bromide in COPD airways trial 5 (GLOW 5; $\mathrm{n}=657$ ), lung function was comparable between glycopyrronium $50 \mu \mathrm{g}$ QD (Breezhaler ${ }^{\circ}$ ) and tiotropium HandiHaler $18 \mu \mathrm{g}$ QD (week 12; least squares mean trough $\mathrm{FEV}_{1}=1.405 \mathrm{~L}$ for both) [75]. Improvements in dyspnea, HRQoL, rescue medication use, and rate of COPD exacerbations, as well as safety, were also similar between groups.

\section{Clinical development of tiotropium Respimat ${ }^{\circledR}$}

pMDIs generate aerosols with high velocity, which leads to considerable oropharyngeal drug deposition, and the necessary coordination of inhalation and actuation is difficult for some patients [76]. On the other hand, most DPIs require a strong inspiratory airflow, which also may be difficult for some patients [76].

\section{Soft mist inhaler}

The only available SMI, Respimat ${ }^{\circ}$, is a pocket-sized, propellant-free device that generates an aerosol from a drug solution effectively and consistently [76]. Respimat ${ }^{\circ}$, which was developed to overcome or minimize some of the limitations of other inhalers [77], uses mechanical energy to generate a fine, slow-moving aerosol cloud (mist) from the drug solution, requires minimal coordination of inhalation and actuation, and does not require high inspiratory flow rates [14]. Further, the fine-particle fraction (approximately 75\%; particles $>1$ to $<5.8 \mu \mathrm{m}$ ) of the mist is nearly twice that in the aerosol cloud emitted from most pMDIs and DPIs [76], and the mist has a lower velocity and a longer duration than the aerosol cloud of pMDIs (mean velocity at a $10-\mathrm{cm}$ distance from the nozzle: $\mathrm{SMI}=0.8 \mathrm{~m} / \mathrm{s} ; \mathrm{pMDIs}=2.0-8.4 \mathrm{~m} / \mathrm{s} ;$ mean duration: $\mathrm{SMI}=1.5 \mathrm{~s} ;$ pMDIs $=0.15-0.36 \mathrm{~s}$ ) [20]. These factors contribute to reduced oropharyngeal drug deposition and increased drug deposition in the lungs [15-17].

\section{Dose response}

Because Respimat ${ }^{\circ}$ provides high drug lung deposition, lower doses of tiotropium were expected to provide comparable efficacy as the doses used with HandiHaler [30]. A 3-week, dose-ranging RCT $(n=202)$ was conducted to compare various tiotropium doses $(1.25 \mu \mathrm{g}$, $2.5 \mu \mathrm{g}, 5 \mu \mathrm{g}, 10 \mu \mathrm{g}$, or $20 \mu \mathrm{g}$ QD) delivered via Respimat ${ }^{\circ}$, placebo delivered via Respimat $^{\circ}$, tiotropium $18 \mu \mathrm{g}$ delivered via HandiHaler, and placebo delivered via HandiHaler ${ }^{\circ}$ [30]. Tiotropium Respimat ${ }^{\circ} 5 \mu \mathrm{g}$ and $20 \mu \mathrm{g}$ significantly improved lung function compared with placebo Respimat $^{\circ}$ (difference in trough $\mathrm{FEV}_{1}$ response $=$ $0.17 \mathrm{~L}$ [both doses]; $p<0.05$ for both) at the end of treatment. Tiotropium Respimat ${ }^{\circ} 10 \mu \mathrm{g}$ also improved lung function but not significantly $(p=0.06)$ more than placebo [30]. Safety was similar across treatment groups.

\section{Pivotal studies}

In a pre-specified pooled analysis of two 30-week studies $(\mathrm{n}=207)$, tiotropium Respimat $5 \mu \mathrm{g}$ and $10 \mu \mathrm{g}$ QD were superior to placebo in improving lung function (day 29; difference in trough $\mathrm{FEV}_{1}$ response $=0.126 \mathrm{~L}$ and $0.127 \mathrm{~L}$, respectively; $p<0.0001$ for both) and were non-inferior to tiotropium HandiHaler $18 \mu \mathrm{g}$ QD (day 29; difference in trough $\mathrm{FEV}_{1}$ response $=0.029 \mathrm{~L}$ and $0.031 \mathrm{~L}$, respectively; $p<0.0001$ for both) [78]. In two identical, short-term, randomized, active- and placebo-controlled trials $(n=719)$, the efficacy and safety of tiotropium Respimat $5 \mu \mathrm{g}$ and $10 \mu \mathrm{g}$ QD were compared with that of ipratropium $36 \mu \mathrm{g}$ QID delivered via a pMDI [27]. At week 12, both tiotropium doses significantly improved lung function compared with ipratropium (difference in trough $\mathrm{FEV}_{1}$ response $=0.064 \mathrm{~L}[p=$ $0.006]$ and $0.095 \mathrm{~L}[p<0.001]$, respectively; difference in trough $\mathrm{FVC}$ response $=0.077 \mathrm{~L}[p>0.01]$ and $0.125 \mathrm{~L}[p<$ $0.01]$, respectively) and compared with placebo (difference in trough $\mathrm{FEV}_{1}$ response $=0.118 \mathrm{~L}$ and $0.149 \mathrm{~L}$, respectively [both $p<0.0001$ ]; difference in trough FVC response $=$ 
$0.132 \mathrm{~L}[p<0.01]$ and $0.180 \mathrm{~L} \quad[p<0.0001]$, respectively) [27]. Both tiotropium doses also significantly reduced rescue medication use compared with placebo $(p=0.0061$ and $p<0.0001$, respectively); however, only the $10-\mu \mathrm{g}$ dose was statistically superior to ipratropium $(p=0.04)$. The longterm efficacy and safety of tiotropium Respimat $5 \mu \mathrm{g}$ and $10 \mu \mathrm{g}$ QD were evaluated in two identical RCTs $(\mathrm{n}=1990)$ [28]. At 1 year of treatment, both tiotropium doses compared with placebo significantly improved lung function (difference in trough $\mathrm{FEV}_{1}$ response $=0.127 \mathrm{~L}$ and $0.150 \mathrm{~L}$, respectively; both $p<0.0001$ ) and HRQoL (difference in SGRQ total score $=-3.5$ and -3.8 , respectively; both $p<$ 0.0001 ) and reduced dyspnea (difference in TDI focal score $=1.05$ and 1.08 , respectively; both $p<0.0001$ ) and mean COPD exacerbation rate/PY (odds ratio $[\mathrm{OR}]=0.75$ $[p<0.01]$ and $0.74[p<0.001]$, respectively). Significantly fewer patients experienced $\geq 1$ exacerbation in the tiotropium groups than in the placebo group (difference $=-6.9$ and $-7.2 \%$, respectively; both $p<0.01$ ). The incidence of gastrointestinal disorders was greater in the tiotropium groups than in the placebo group (dry mouth: $5 \mu \mathrm{g}=7.2 \%$, $10 \mu \mathrm{g}=14.5 \%$, placebo $=2.1 \%$; constipation: $5 \mu \mathrm{g}=2.1 \%$, $10 \mu \mathrm{g}=2.2 \%$, placebo $=1.5 \%)$. In another 1 -year RCT $(\mathrm{n}=$ 3991), the efficacy and safety of tiotropium Respimat $5 \mu \mathrm{g}$ QD were evaluated [29]. Patients were permitted to use usual therapy (any concurrent COPD medications except inhaled anticholinergics) to reflect closely the place of tiotropium in COPD management. At week 48, tiotropium $5 \mu \mathrm{g}$ compared with placebo significantly improved lung function (adjusted mean difference in trough $\mathrm{FEV}_{1}=0.102$ $\mathrm{L}$; adjusted mean difference in trough $\mathrm{FVC}=0.168 \mathrm{~L}$; both $p<0.0001$ ) and improved HRQoL (adjusted mean difference in SGRQ total score $=-2.9 \mathrm{U} ; p<0.0001$ ). Further, the proportion of patients having $\geq 1$ exacerbation was lower in the tiotropium group compared with the placebo group ( 35.3 and $43.1 \%$, respectively; $\mathrm{HR}=0.69$ [ie, $31 \%$ reduction in the risk of exacerbations with tiotropium; $p<$ 0.0001) [29]. Collectively, results of these studies showed that tiotropium Respimat $5 \mu \mathrm{g}$ QD was efficacious as maintenance treatment for COPD and for reducing exacerbations, leading to the approval of Spiriva ${ }^{\circ}$ Respimat $^{\circ}$ in the EU (2007), US (2014), and other countries [79].

\section{Observational studies}

The effectiveness of tiotropium Respimat ${ }^{\circ} 5 \mu \mathrm{g}$ QD was evaluated in a 6-week open-label observational study $(\mathrm{n}=1230)$ [80]. Tiotropium improved physical function as indicated by a significant increase in the mean Physical Function subdomain (PF-10) score (baseline, 49.0 points; week $6,62.3$ points; difference, 13.4 points $[\mathrm{p}<0.001]$ ). Further, the proportion of patients achieving a $\geq 10$-point improvement in PF-10 score was not significantly different between smokers and non-smokers (61.4 and 61.6\%, respectively; difference, $p=0.93$ ). Adverse events were reported by $4.0 \%$ of patients, the most common being respiratory symptoms and dry mouth.

\section{Landmark safety trial}

The TIOtropium Safety and Performance In Respimat ${ }^{\circ}$ (TIOSPIR ${ }^{\circ}$ trial $(\mathrm{n}=17,315)$ was conducted to confirm the safety and efficacy of tiotropium Respimat ${ }^{\circ}$ in a large population of patients with COPD [81]. By having an adequate patient population size $(>17,000$ patients at $>$ 1200 investigator sites in 50 countries), broad inclusion criteria to closely reflect real-world patients with COPD, and sufficient treatment duration, analyses of all-cause mortality and time to first COPD exacerbation were possible. During a 2.3-year mean follow-up period, tiotropium Respimat ${ }^{\circ} 5 \mu \mathrm{g}$ and $2.5 \mu \mathrm{g}$ QD were non-inferior to tiotropium HandiHaler $18 \mu \mathrm{g}$ QD in the risk of death (both $p<0.05$ ) and not superior in the risk of exacerbation ( $p=0.42$ and $p=0.56$, respectively) [81]. In patients with a history of cardiac arrhythmia, tiotropium Respimat $^{\bullet} 2.5 \mu \mathrm{g}$ and tiotropium HandiHaler ${ }^{\circ} 18 \mu \mathrm{g}$ had a similar impact on survival as measured by all-cause mortality. In addition to these analyses, various post hoc analyses were conducted to assess the impact of geographical variations [82] on COPD outcomes, to evaluate spirometry outcomes [83], and to determine risk factors for exacerbations [84]. Tiotropium Respimat ${ }^{\circ} 5 \mu \mathrm{g}$ was associated with a similar improvement in trough FVC and a comparable rate of decline in $\mathrm{FEV}_{1}$ as tiotropium HandiHaler $18 \mu \mathrm{g}$ in the spirometry outcomes analysis [83]. In a multivariate analysis, baseline pulmonary maintenance medication was predictive of, and ICS use was associated with, increased exacerbation risk [84].

TIOSPIR $^{\circ}$ was conducted because a numerical, but not statistically significant, imbalance in the number of deaths had been noted in meta-analyses of Respimat ${ }^{\circ}$ trials, between tiotropium Respimat ${ }^{\circ}$ and placebo Respimat $^{\ominus}$ or tiotropium HandiHaler, particularly for patients with known cardiac disorders [85-87]. Valid concerns were quickly raised, however, about the meta-analyses' methodologies and conclusions, particularly the analysis conducted by Singh et al. [85], which included five of the aforementioned RCTs [2729 , 88-90]. For example, in that analysis, conclusions were based on three 1-year studies that had mortality imbalances (and not based on two 12-week studies that showed no imbalance) [88]. Additionally, in one of the studies with mortality imbalances, the placebo arm had an unusually low $(0.77 \%)$ mortality rate compared with that observed in other studies (1.5-2.5\% or higher) [88]. Further, fatal cases were incorrectly assigned to treatment groups $[88,91]$, and a 6 -month trial of $>850$ patients [92], which had only two deaths in the tiotropium Respimat ${ }^{\circ}$ arm and five deaths in the placebo Respimat $^{\oplus}$ arm, was not included $[88,91]$. 
Table 2 Tiotropium - summary table of evidence

\begin{tabular}{|c|c|c|c|c|c|}
\hline Study & $\begin{array}{l}\text { Patients } \\
\text { (N) }\end{array}$ & $\begin{array}{l}\text { Treatment } \\
\text { arms }\end{array}$ & Primary endpoint results* & $\begin{array}{l}\text { Proportion of } \\
\text { patients with } \\
\text { adverse events }\end{array}$ & Conclusion of the study \\
\hline $\begin{array}{l}\text { Casaburi } \\
2000[21]\end{array}$ & 470 & $\begin{array}{l}\text { - Tiotropium } \\
18 \mu \mathrm{g} \text { QD } \\
\text { - Placebo }\end{array}$ & $\begin{array}{l}\text { Trough FEV }{ }_{1} \text { response: } \\
0.11 \mathrm{~L} \text { vs }-0.04 \mathrm{~L}(p< \\
0.001)\end{array}$ & $\begin{array}{l}\text { Overall adverse } \\
\text { events: } \\
61.6 \% \text { vs } 66.5 \% \\
\text { Dry mouth: } \\
9.3 \% \text { vs } 1.6 \% \\
(p<0.05)\end{array}$ & Tiotropium was safe and effective \\
\hline $\begin{array}{l}\text { Casaburi } \\
2002[22]\end{array}$ & 921 & $\begin{array}{l}\text { - Tiotropium } \\
18 \mu \mathrm{g} \text { QD } \\
\text { - Placebo }\end{array}$ & $\begin{array}{l}\text { Trough } \mathrm{FEV}_{1} \text { response: } \\
0.11 \mathrm{~L} \text { to } 0.13 \mathrm{~L} \\
\text { (tiotropium; } p<0.01 \mathrm{vs} \\
\text { placebo) }\end{array}$ & $\begin{array}{l}\text { Overall adverse } \\
\text { events: } \\
90.0 \% \text { vs } 91.1 \% \\
\text { Dry mouth: } \\
16.0 \% \text { vs } 2.7 \% \\
(p<0.05)\end{array}$ & $\begin{array}{l}\text { Tiotropium significantly improved lung function and HRQOL } \\
\text { and reduced dyspnea, COPD exacerbations, and } \\
\text { hospitalizations }\end{array}$ \\
\hline $\begin{array}{l}\text { Vincken } \\
2002[34]\end{array}$ & 535 & $\begin{array}{l}\text { - Tiotropium } \\
18 \mu \mathrm{g} \text { QD } \\
\text { • Ipratropium } \\
40 \mu \mathrm{g} \text { QID }\end{array}$ & $\begin{array}{l}\text { Trough FEV } 1 \text { response: } \\
0.12 L \text { vs }-0.03 L(p< \\
0.001)\end{array}$ & $\begin{array}{l}\text { Adverse events } \\
\text { leading to } \\
\text { discontinuation: } \\
10.1 \% \text { vs } 12.8 \% \\
\text { Dry mouth: } \\
12.1 \% \text { vs } 6.1 \% \\
(p=0.03)\end{array}$ & $\begin{array}{l}\text { Tiotropium significantly improved lung function and HRQOL } \\
\text { and reduced dyspnea and COPD exacerbations compared } \\
\text { with ipratropium }\end{array}$ \\
\hline $\begin{array}{l}\text { Donohue } \\
2002[35]\end{array}$ & $623^{* *}$ & $\begin{array}{l}\text { - Tiotropium } \\
18 \mu \mathrm{g} \text { QD } \\
\text { - Salmeterol } \\
50 \mu \mathrm{g} \text { BID }\end{array}$ & $\begin{array}{l}\text { Trough FEV } 1 \text { response: } \\
0.14 L \text { vs } 0.09 L(p<0.01)\end{array}$ & $\begin{array}{l}\text { Dry mouth: } \\
10 \% \text { vs NA }\end{array}$ & $\begin{array}{l}\text { Tiotropium significantly improved lung function and } \\
\text { reduced dyspnea compared with salmeterol }\end{array}$ \\
\hline $\begin{array}{l}\text { Brusasco } \\
2003[36]\end{array}$ & 1207 & $\begin{array}{l}\text { - Tiotropium } \\
18 \mu \mathrm{g} \text { QD } \\
\text { - Salmeterol } \\
50 \mu \mathrm{g} \text { BID } \\
\text { - Placebo }\end{array}$ & $\begin{array}{l}\text { COPD exacerbation rate: } \\
1.07 \text { vs } 1.23 \text { vs } 1.49 \\
\text { ( } p<0.05 \text { for tiotropium } \\
\text { vs placebo) }\end{array}$ & $\begin{array}{l}\text { Dry mouth: } \\
8.2 \% \text { vs } 1.7 \% \text { vs } \\
2.3 \%\end{array}$ & $\begin{array}{l}\text { Tiotropium significantly improved lung function compared } \\
\text { with salmeterol; improved } \mathrm{HRQ} \text { L } \mathrm{L} \text { and reduced dyspnea } \\
\text { and COPD exacerbations compared with placebo }\end{array}$ \\
\hline $\begin{array}{l}\text { O'Donnell } \\
2004[45]\end{array}$ & 187 & $\begin{array}{l}\text { - Tiotropium } \\
18 \mu \mathrm{g} \text { QD } \\
\text { - Placebo }\end{array}$ & $\begin{array}{l}\text { Difference in endurance } \\
\text { time between tiotropium } \\
\text { and placebo: } \\
105 \text { s ( } p=0.0098)\end{array}$ & $\begin{array}{l}\text { Overall adverse } \\
\text { events: } \\
36.7 \% \text { vs } 41.0 \%\end{array}$ & $\begin{array}{l}\text { Tiotropium significantly reduced lung hyperinflation at rest } \\
\text { and exercise and improved exertional dyspnea and } \\
\text { endurance time }\end{array}$ \\
\hline $\begin{array}{l}\text { Niewoehner } \\
2005 \text { [37] }\end{array}$ & 1829 & $\begin{array}{l}\text { - Tiotropium } \\
18 \mu \mathrm{g} \text { QD } \\
\text { - Placebo }\end{array}$ & $\begin{array}{l}\text { Percentage of patients } \\
\text { with } \geq 1 \text { exacerbation: } \\
27.9 \% \text { vs } 32.3 \% \text { ( } p= \\
0.037) \\
\text { Percentage of patients } \\
\text { with COPD-related } \\
\text { hospitalization: } \\
7.0 \% \text { vs } 9.5 \%(p=0.056)\end{array}$ & $\begin{array}{l}\text { Serious adverse } \\
\text { events: } \\
18 \% \text { vs } 17 \%\end{array}$ & $\begin{array}{l}\text { Tiotropium reduced COPD exacerbations, COPD-related } \\
\text { hospitalization, and healthcare utilization compared with } \\
\text { placebo }\end{array}$ \\
\hline $\begin{array}{l}\text { Dusser } 2006 \\
{[24]}\end{array}$ & 1010 & $\begin{array}{l}\text { - Tiotropium } \\
18 \mu \mathrm{g} \text { QD } \\
\text { - Placebo }\end{array}$ & $\begin{array}{l}\text { Percentage of patients } \\
\text { with } \geq 1 \text { exacerbation: } \\
49.9 \% \text { vs } 60.3 \%(p<0.01)\end{array}$ & $\begin{array}{l}\text { Overall adverse } \\
\text { events: } \\
46.4 \% \text { vs } 45.1 \% \\
\text { Dry mouth: } \\
4.0 \% \text { vs } 1.4 \%\end{array}$ & $\begin{array}{l}\text { Tiotropium significantly improved lung function and } \\
\text { reduced COPD exacerbations and COPD-associated health } \\
\text { resource use compared with placebo }\end{array}$ \\
\hline $\begin{array}{l}\text { Verkindre } \\
2006[32]\end{array}$ & 100 & $\begin{array}{l}\text { - Tiotropium } \\
18 \mu \mathrm{g} \text { QD } \\
\text { - Placebo }\end{array}$ & $\begin{array}{l}\text { Trough FVC: } \\
\text { Difference: } 0.20 \mathrm{~L} \\
(p<0.05)\end{array}$ & $\begin{array}{l}\text { Adverse events } \\
\text { leading to } \\
\text { discontinuation: } \\
2 \% \text { vs } 11 \% \\
\text { Dry mouth: } \\
2 \% \text { vs } 0 \%\end{array}$ & $\begin{array}{l}\text { Tiotropium significantly improved FVC, lung hyperinflation, } \\
\text { walking distance, and HRQOL }\end{array}$ \\
\hline $\begin{array}{l}\text { Bateman } \\
2008[66]\end{array}$ & 107 & $\begin{array}{l}\text { - Tiotropium } \\
18 \mu \mathrm{g} Q \mathrm{QD} \\
\text { • Fluticasone/ } \\
\text { salmeterol } \\
250 / 50 \mu \mathrm{g} \text { BID }\end{array}$ & $\begin{array}{l}\mathrm{FEV}_{1} \mathrm{AUC}_{0-12 h}: \\
1.55 \mathrm{~L} \text { vs } 1.57 \mathrm{~L}(p=0.63)\end{array}$ & $\begin{array}{l}\text { Overall adverse } \\
\text { events: } \\
41.1 \% \text { vs } 43.1 \% \\
\text { Dry mouth: } \\
3.6 \% \text { vs 3.9\% }\end{array}$ & $\begin{array}{l}\text { Tiotropium improved lung function similar to fluticasone/ } \\
\text { salmeterol combination }\end{array}$ \\
\hline $\begin{array}{l}\text { Tashkin } 2008 \\
{[26]}\end{array}$ & 5993 & $\begin{array}{l}\text { - Tiotropium } \\
18 \mu \mathrm{g} \text { QD } \\
\text { - Placebo }\end{array}$ & $\begin{array}{l}\text { Rate of decline in FEV } \\
\text { before bronchodilation: } \\
0.030 \mathrm{~L} \text { vs } 0.030 \mathrm{~L}(p= \\
0.95)\end{array}$ & $\begin{array}{l}\text { Overall adverse } \\
\text { events: } \\
92.6 \% \text { vs } 92.3 \%\end{array}$ & $\begin{array}{l}\text { Tiotropium significantly improved lung function, improved } \\
\text { HRQoL, reduced exacerbations, but did not significantly } \\
\text { reduce rate of decline in } \mathrm{FEV}_{1} \text { compared with placebo }\end{array}$ \\
\hline
\end{tabular}


Table 2 Tiotropium - summary table of evidence (Continued)

\begin{tabular}{|c|c|c|c|c|c|}
\hline Study & $\begin{array}{l}\text { Patients } \\
(\mathrm{N})\end{array}$ & $\begin{array}{l}\text { Treatment } \\
\text { arms }\end{array}$ & Primary endpoint results* & $\begin{array}{l}\text { Proportion of } \\
\text { patients with } \\
\text { adverse events }\end{array}$ & Conclusion of the study \\
\hline & & & $\begin{array}{l}\text { Rate of decline in } \mathrm{FEV}_{1} \\
\text { after bronchodilation: } \\
0.040 \mathrm{~L} \text { vs } 0.042 \mathrm{~L}(p= \\
0.21)\end{array}$ & & \\
\hline $\begin{array}{l}\text { Tonnel } 2008 \\
\text { [23] }\end{array}$ & 554 & $\begin{array}{l}\text { - Tiotropium } \\
18 \mu \mathrm{g} \mathrm{QD} \\
\text {. Placebo }\end{array}$ & $\begin{array}{l}\text { Proportion of patients } \\
\text { with improvement in } \\
\text { HRQoL }{ }^{\mathrm{a}} \text { : } \\
59.1 \% \text { vs } 48.2 \% \text { ( } p= \\
0.029 \text { ) }\end{array}$ & $\begin{array}{l}\text { Patients with } \geq 1 \\
\text { adverse event: } \\
60.9 \% \text { vs } 67.0 \% \\
\text { Dry mouth: } \\
1.1 \% \text { vs } 0.7 \%\end{array}$ & $\begin{array}{l}\text { Tiotropium significantly improved lung function, improved } \\
\text { HRQOL, and reduced exacerbations }\end{array}$ \\
\hline $\begin{array}{l}\text { Voshaar } \\
2008[27]\end{array}$ & 719 & $\begin{array}{l}\text { - Tiotropium } \\
5 \mu \mathrm{g} \mathrm{QD} \\
\cdot \text { Tiotropium } \\
10 \mu \mathrm{g} \text { QD } \\
\text { - Ipratropium } \\
36 \mu \mathrm{g} \mathrm{QID} \mathrm{vs} \\
\text { placebo }\end{array}$ & $\begin{array}{l}\text { Trough } \mathrm{FEV}_{1} \text { response } \\
\text { treatment differences: } \\
\text { tiotropium } 5 \mu \mathrm{\mu g}- \\
\text { placebo: } \\
0.118 \mathrm{~L}(p<0.0001) \\
\text { tiotropium } 10 \mu \mathrm{g}- \\
\text { placebo: } 0.149 \mathrm{~L}(p< \\
\text { 0.0001) } \\
\text { tiotropium } 5 \mu \mathrm{g}- \\
\text { ipratropium: } \\
\text { 0.064 } \mathrm{L}(p=0.006) \\
\text { tiotropium } 10 \mu \mathrm{g}- \\
\text { ipratropium: } 0.095 \mathrm{~L}(p< \\
\text { 0.0001) }\end{array}$ & $\begin{array}{l}\text { Overall adverse } \\
\text { events: } \\
52.8 \% \text { vs } 60.0 \% \\
\text { vs } 59.6 \% \text { vs } \\
59.1 \% \\
\text { Dry mouth: } \\
8.3 \% \text { vs } 10.0 \% \text { vs } \\
3.9 \% \text { vs } 2.2 \%\end{array}$ & $\begin{array}{l}\text { Tiotropium (via Respimat }{ }^{\oplus} \text { ) significantly improved lung } \\
\text { function compared with ipratropium (pMDI) and placebo }\end{array}$ \\
\hline $\begin{array}{l}\text { Wedzicha } \\
2008[67]\end{array}$ & 1323 & $\begin{array}{l}\text { - Tiotropium } \\
18 \mu \mathrm{g} \text { QD } \\
\text { - Fluticasone/ } \\
\text { salmeterol } \\
500 / 50 \mu \mathrm{g} \mathrm{BID}\end{array}$ & $\begin{array}{l}\text { Modeled annual rate of } \\
\text { exacerbations: } \\
1.32 \text { vs } 1.28(p=0.656)\end{array}$ & $\begin{array}{l}\text { Overall adverse } \\
\text { events: } 62 \% \text { vs } \\
66 \%\end{array}$ & $\begin{array}{l}\text { Tiotropium was similar to fluticasone/salmeterol in } \\
\text { exacerbation efficacy }\end{array}$ \\
\hline $\begin{array}{l}\text { Bateman } \\
2010[28]\end{array}$ & 1990 & $\begin{array}{l}\text { - Tiotropium } \\
5 \mu \mathrm{g} \text { QD } \\
\cdot \text { Tiotropium } \\
10 \mu \mathrm{g} \text { QD } \\
\text { - Placebo }\end{array}$ & $\begin{array}{l}\text { Trough } \mathrm{FEV}_{1} \text { response: } \\
\text { tiotropium } 5 \mu \mathrm{g} \text { vs } \\
\text { placebo: } \\
0.127 \mathrm{~L}(p<0.0001) \\
\text { tiotropium } 10 \mu \mathrm{g} \text { vs } \\
\text { placebo: } 0.150 \mathrm{~L} \text { ( } p< \\
\text { 0.0001) }\end{array}$ & $\begin{array}{l}\text { Overall adverse } \\
\text { events: } \\
75.4 \% \text { vs } 78.7 \% \\
\text { vs } 76.9 \%\end{array}$ & $\begin{array}{l}\text { Tiotropium (via Respimat }{ }^{\oplus} \text { ) significantly improved lung } \\
\text { function and HRQOL and reduced dyspnea and } \\
\text { exacerbations compared with placebo }\end{array}$ \\
\hline $\begin{array}{l}\text { Bateman } \\
2010[29]\end{array}$ & 3991 & $\begin{array}{l}\text { - Tiotropium } \\
5 \mu g \text { QD } \\
\text { - Placebo }\end{array}$ & $\begin{array}{l}\text { Trough FEV }{ }_{1} \text { response: } \\
0.119 L \text { vs } 0.018 \mathrm{~L}(p< \\
0.0001) \\
\text { Time to first } \\
\text { exacerbation: } \\
169 \text { days vs } 119 \text { days } \\
(p<0.0001)\end{array}$ & $\begin{array}{l}\text { Overall adverse } \\
\text { events: } \\
70.1 \% \text { vs } 69.3 \% \text {; } \\
\text { Dry mouth: } \\
3.1 \% \text { vs } 1.4 \%\end{array}$ & $\begin{array}{l}\text { Tiotropium (via Respimat }{ }^{\oplus} \text { ) significantly improved lung } \\
\text { function and HRQoL and reduced exacerbations compared } \\
\text { with placebo }\end{array}$ \\
\hline $\begin{array}{l}\text { Vogelmeier } \\
2011[39]\end{array}$ & 7376 & $\begin{array}{l}\text { - Tiotropium } \\
18 \mu \mathrm{g} \text { QD } \\
\text { - Salmeterol } \\
50 \mu \mathrm{\mu g} \text { BID }\end{array}$ & $\begin{array}{l}\text { Time to first } \\
\text { exacerbation: } \\
187 \text { days vs } 145 \text { days } \\
(p<0.001)\end{array}$ & $\begin{array}{l}\text { Serious adverse } \\
\text { events: } \\
14.7 \% \text { vs } 16.5 \%\end{array}$ & $\begin{array}{l}\text { Tiotropium significantly reduced exacerbations compared } \\
\text { with salmeterol }\end{array}$ \\
\hline $\begin{array}{l}\text { Wise } 2013 \\
\text { [81] }\end{array}$ & 17,135 & $\begin{array}{l}\cdot \text { Tiotropium } \\
2.5 \mu \mathrm{gQD} \\
\cdot \text { Tiotropium } \\
5 \mu \mathrm{g} \mathrm{QD} \\
\cdot \text { Tiotropium } \\
18 \mu \mathrm{g} \mathrm{QD}\end{array}$ & $\begin{array}{l}\text { Deaths: } \\
7.7 \% \text { vs } 7.4 \% \text { vs } 7.7 \% \\
\text { Proportion of patients } \\
\text { with exacerbations: } \\
49.4 \% \text { vs } 47.9 \% \text { vs } 48.9 \%\end{array}$ & $\begin{array}{l}\text { Serious adverse } \\
\text { events: } \\
33.8 \% \text { vs } 32.4 \% \\
\text { vs } 32.4 \%\end{array}$ & $\begin{array}{l}\text { Tiotropium } 2.5 \mu \mathrm{g} \text { or } 5 \mu \mathrm{g}\left(\text { (via Respimat }^{\circledR}\right) \text { was similar to } \\
\text { tiotropium } 18 \mu \mathrm{g}\left(\text { via HandiHaler }{ }^{\oplus}\right) \text { in safety and } \\
\text { exacerbation efficacy }\end{array}$ \\
\hline
\end{tabular}

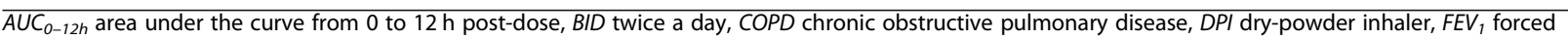
expiratory volume in $1 \mathrm{~s}, F V C$ forced vital capacity, $H R Q o L$ health-related quality of life, $N A$ not available, $p M D I$ pressurized metered-dose inhaler, $Q D$ once daily, QID four times a day, SGRQ St. George's Respiratory Questionnaire

a Reduction of at least four units in the SGRQ score

*For studies in which the primary endpoint was not specified, results of lung function are included.**Includes the total number of patients in the tiotropium, salmeterol, and placebo groups

Tiotropium $18 \mu \mathrm{g}$ delivered via HandiHaler'; tiotropium $2.5 \mu \mathrm{g}, 5 \mu \mathrm{g}$, and $10 \mu \mathrm{g}$ delivered via Respimat ${ }^{\oplus}$; other drugs delivered via a pMDI or a DPI 
Table 3 Tiotropium/olodaterol combination - summary table of evidence

\begin{tabular}{|c|c|c|c|c|c|}
\hline Study & $\begin{array}{l}\text { Patients } \\
(\mathrm{N})\end{array}$ & Treatment arms & Primary endpoint results & $\begin{array}{l}\text { Proportion of } \\
\text { patients with } \\
\text { adverse } \\
\text { events }\end{array}$ & Conclusion of the study \\
\hline $\begin{array}{l}\text { Buhl } 2015 \\
{[95]}\end{array}$ & 5162 & $\begin{array}{l}\text { - Tiotropium+olodaterol } \\
2.5 / 5 \mu \mathrm{g} Q \mathrm{QD} \\
\text { - Tiotropium+olodaterol } \\
5 / 5 \mu \mathrm{g} \mathrm{QD} \\
\text { - Tiotropium } 2.5 \mu \mathrm{g} \mathrm{QD} \\
\text { - Tiotropium } 5 \mu \mathrm{g} \mathrm{QD} \\
\text { - Olodaterol } 5 \mu \mathrm{g} \mathrm{QD}\end{array}$ & 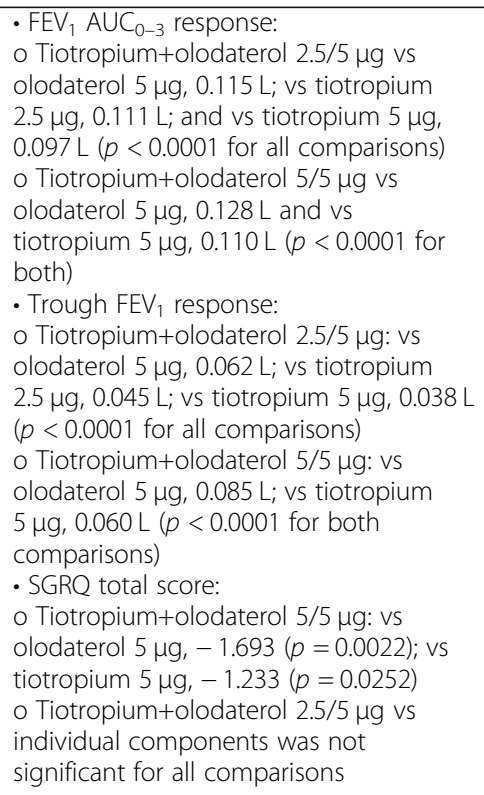 & $\begin{array}{l}74.7 \% \text { vs } \\
74.0 \% \text { vs } \\
73.4 \% \text { vs } \\
73.3 \% \text { vs } \\
76.6 \%\end{array}$ & $\begin{array}{l}\text { Tiotropium+olodaterol improved lung } \\
\text { function and } H R Q \circ L \text { compared with } \\
\text { monocomponents }\end{array}$ \\
\hline $\begin{array}{l}\text { Beeh } 2015 \\
\text { [96] }\end{array}$ & 259 & $\begin{array}{l}\text { - Tiotropium+olodaterol } \\
2.5 / 5 \mu \mathrm{g} Q \mathrm{QD} \\
\text { - Tiotropium+olodaterol } \\
5 / 5 \mu \mathrm{gD} \\
\text { - Tiotropium } 2.5 \mu \mathrm{g} \mathrm{QD} \\
\text { - Tiotropium } 5 \mu \mathrm{g} \mathrm{QD} \\
\text { - Olodaterol } 5 \mu \mathrm{g} \mathrm{QD} \\
\text { - Placebo }\end{array}$ & $\begin{array}{l}\text { - } \mathrm{FEV}_{1} \mathrm{AUC}_{0-24} \text { response: } \\
\text { o Tiotropium+olodaterol } 2.5 / 5 \mu \mathrm{g} \text { : vs } \\
\text { olodaterol } 5 \mu \mathrm{g}, 0.111 \mathrm{~L} \text {; vs tiotropium } \\
2.5 \mu \mathrm{g}, 0.124 \mathrm{~L} \text {; vs tiotropium } 5 \mu \mathrm{g}, 0.107 \\
\mathrm{~L} ; \mathrm{vs} \text { placebo, } 0.277 \mathrm{~L}(p<0.001 \text { for all } \\
\text { comparisons) } \\
\text { o Tiotropium+olodaterol } 5 / 5 \mu \mathrm{g} \text { : vs } \\
\text { olodaterol } 5 \mu \mathrm{g}, 0.115 \mathrm{~L} \text {; vs tiotropium } \\
2.5 \mu \mathrm{g}, 0.127 \mathrm{~L} ; \mathrm{vs} \text { tiotropium } 5 \mu \mathrm{g}, 0.110 \\
\mathrm{~L} ; \mathrm{vs} \text { placebo, } 0.280 \mathrm{~L}(p<0.0001 \text { for all } \\
\text { comparisons) }\end{array}$ & $\begin{array}{l}36.0 \% \text { vs } \\
37.4 \% \text { vs } \\
39.4 \% \text { vs } \\
44.2 \% \text { vs } \\
37.7 \% \text { vs } \\
46.4 \%\end{array}$ & $\begin{array}{l}\text { Tiotropium+olodaterol improved lung } \\
\text { function over } 24 \mathrm{~h} \text { compared with } \\
\text { monocomponents }\end{array}$ \\
\hline $\begin{array}{l}\text { O'Donnell } \\
2017 \text { [97] }\end{array}$ & 586 & $\begin{array}{l}\text { - Tiotropium+olodaterol } \\
2.5 / 5 \mu \mathrm{g} Q \mathrm{QD} \\
\text { - Tiotropium+olodaterol } \\
5 / 5 \mu \mathrm{g} \mathrm{QD} \\
\text { - Tiotropium } 5 \mu \mathrm{g} \mathrm{QD} \\
\text { - Olodaterol } 5 \mu \mathrm{g} \mathrm{QD} \\
\text { - Placebo }\end{array}$ & $\begin{array}{l}\text { - Inspiratory capacity: } \\
\text { o Tiotropium+olodaterol } 2.5 / 5 \mu \mathrm{g} \text { : vs } \\
\text { olodaterol } 5 \mu \mathrm{g}, 0.090 \mathrm{~L} \text {; vs tiotropium } \\
5 \mu \mathrm{g}, 0.092 \mathrm{~L} \text {; vs placebo, } 0.245 \mathrm{~L} \text { ( } p< \\
0.0001 \text { for all comparisons) } \\
\text { o Tiotropium+olodaterol } 5 / 5 \mu \mathrm{g} \text { : vs } \\
\text { olodaterol } 5 \mu \mathrm{gg}, 0.099 \mathrm{~L} \text {; vs tiotropium } \\
5 \mu \mathrm{g}, 0.101 \mathrm{~L} \text {; vs placebo, } 0.254 \mathrm{~L} \text { ( } p< \\
0.0001 \text { for all comparisons) } \\
\text { - Exercise endurance time during } \\
\text { constant work-rate cycle ergometry } \\
\text { (improvement): } \\
\text { o Tiotropium+olodaterol } 2.5 / 5 \mu \mathrm{g} \text { : vs } \\
\text { olodaterol } 5 \mu \mathrm{g}, 7.3 \% \text { ( } p<0.01 \text { ); vs } \\
\text { tiotropium } 5 \mu \mathrm{g}, 3.5 \% \text {; vs placebo, } 19.2 \% \\
(p<0.0001) \\
\text { o Tiotropium+olodaterol } 5 / 5 \mu \mathrm{gg} \text { : vs } \\
\text { olodaterol } 5 \mu \mathrm{g}, 5.6 \% \text { ( } p<0.05 \text { ); vs } \\
\text { tiotropium } 5 \mu \mathrm{g}, 1.9 \% \text {; vs placebo, } 17.3 \% \\
(p<0.0001)\end{array}$ & $\begin{array}{l}36.3 \% \text { vs } \\
40.0 \% \text { vs } \\
38.3 \% \text { vs } \\
40.2 \% \text { vs } \\
40.8 \%\end{array}$ & $\begin{array}{l}\text { Tiotropium+olodaterol improved lung } \\
\text { hyperinflation and exercise tolerance } \\
\text { compared with monotherapies }\end{array}$ \\
\hline $\begin{array}{l}\text { Maltais } \\
2018 \text { [98] }\end{array}$ & 404 & $\begin{array}{l}\cdot \text { Tiotropium+olodaterol } \\
2.5 / 5 \mu \mathrm{g} Q \mathrm{QD} \\
\cdot \text { Tiotropium+olodaterol } \\
5 / 5 \mu \mathrm{QD} \\
\text { - Placebo }\end{array}$ & $\begin{array}{l}\text { - Endurance time during constant work- } \\
\text { rate cycle ergometry: } \\
\text { o Tiotropium+olodaterol } 5 / 5 \mu \mathrm{g} \text { vs } \\
\text { placebo, } 14 \%(p=0.02) \\
\text { o Tiotropium+olodaterol } 2.5 / 5 \mu \mathrm{g} \text { vs } \\
\text { placebo, } 9 \%(p=0.14)\end{array}$ & $\begin{array}{l}54.9 \% \text { vs } \\
43.9 \% \text { vs } \\
50.8 \%\end{array}$ & $\begin{array}{l}\text { Tiotropium+olodaterol improved } \\
\text { endurance time compared with placebo } \\
\text { during cycle ergometry }\end{array}$ \\
\hline Singh & 1621 & - Tiotropium+olodaterol & - SGRQ total score (difference): & OTEMTO 1: & Tiotropium+olodaterol improved lung \\
\hline
\end{tabular}


Table 3 Tiotropium/olodaterol combination - summary table of evidence (Continued)

\begin{tabular}{|c|c|c|c|c|c|}
\hline Study & $\begin{array}{l}\text { Patients } \\
(\mathrm{N})\end{array}$ & Treatment arms & Primary endpoint results & $\begin{array}{l}\text { Proportion of } \\
\text { patients with } \\
\text { adverse } \\
\text { events }\end{array}$ & Conclusion of the study \\
\hline 2015 [99] & & $\begin{aligned} & 2.5 / 5 \mu \mathrm{g} Q D \\
& \text { - Tiotropium+olodaterol } 5 / 5 \mu \mathrm{QD} \\
& \text { - Tiotropium } 5 \mu \mathrm{g} Q D \\
& \text { - Placebo }\end{aligned}$ & $\begin{array}{l}\text { O Tiotropium+olodaterol } 5 / 5 \mu \mathrm{g} \text { : vs } \\
\text { tiotropium } 5 \mu \mathrm{g},-2.10(p<0.01) \text {; vs } \\
\text { placebo, }-4.67(p<0.0001) \\
\text { o Tiotropium+olodaterol } 2.5 / 5 \mu \mathrm{g} \text { : vs } \\
\text { tiotropium } 5 \mu \mathrm{g},-1.27 \text {; vs placebo, - } \\
3.85(p<0.0001) \\
\text { - } \mathrm{FEV}_{1} \mathrm{AUC}_{0-3} \text { response: } \\
\text { o Both tiotropium+olodaterol } 2.5 / 5 \mu \mathrm{g} \\
\text { and } 5 / 5 \mu \mathrm{g} \text { significantly improved }(p< \\
0.0001) \mathrm{FEV}_{1} \mathrm{AUC}_{0-3} \text { response compared } \\
\text { with placebo and tiotropium } 5 \mu \mathrm{g}\end{array}$ & $\begin{array}{l}42.6 \% \text { vs } \\
44.8 \% \text { vs } \\
44.3 \% \text { vs } \\
51.5 \% \\
\text { OTEMTO } 2: \\
45.5 \% \text { vs } \\
43.1 \% \text { vs } \\
45.8 \% \text { vs } \\
46.0 \%\end{array}$ & $\begin{array}{l}\text { function and QoL compared with } \\
\text { placebo and tiotropium }\end{array}$ \\
\hline $\begin{array}{l}\text { Beeh } 2016 \\
{[100]}\end{array}$ & 229 & $\begin{array}{l}\text { - Tiotropium+olodaterol } \\
\text { 2.5/5 } \mathrm{gg} \mathrm{QD} \\
\text { - Tiotropium+olodaterol } \\
5 / 5 \mu \mathrm{gD} \\
\text { - Salmeterol/fluticasone } \\
50 / 500 \mu \mathrm{g} \mathrm{BID} \\
\text { - Salmeterol/fluticasone } \\
50 / 250 \mu \mathrm{g} \mathrm{BID}\end{array}$ & $\begin{array}{l}\text { - } \mathrm{FEV}_{1} \mathrm{AUC}_{0-12} \text { response: } \\
\text { o } 0.295 \mathrm{~L} \text { Vs } 0.317 \mathrm{~L} \text { vs } 0.188 \mathrm{~L} \text { vs } 0.192 \mathrm{~L} \\
(p<0.0001 \text { for comparisons of } \\
\text { tiotropium+olodaterol vs salmeterol/ } \\
\text { fluticasone) }\end{array}$ & $\begin{array}{l}34.4 \% \text { vs } \\
33.9 \% \text { vs } \\
37.0 \% \text { vs } \\
29.7 \%\end{array}$ & $\begin{array}{l}\text { Tiotropium+olodaterol QD provided } \\
\text { superior improvement in lung function } \\
\text { compared with salmeterol/fluticasone } \\
\text { BID }\end{array}$ \\
\hline $\begin{array}{l}\text { Troosters } \\
2018[101]\end{array}$ & 303 & $\begin{array}{l}\text { - Tiotropium+olodaterol } \\
5 / 5 \mu \mathrm{g} Q \mathrm{QD} \\
\text { - Tiotropium+olodaterol } \\
5 / 5 \mu \mathrm{g} \text { QD plus } 8 \\
\text { weeks of ExT } \\
\text { - Tiotropium } 5 \mu \mathrm{g} \\
\text { - Placebo }\end{array}$ & $\begin{array}{l}\text { - Exercise endurance time by shuttle walk } \\
\text { test (increase): } \\
\text { o Tiotropium+olodaterol } 5 / 5 \mu \mathrm{g} \text { QD vs } \\
\text { placebo, } 29.2 \%(p=0.0109) \\
\text { O Tiotropium+olodaterol } 5 / 5 \mu \mathrm{g} \text { QD plus } \\
8 \text { weeks of ExT vs placebo, } 45.8 \% \text { ( } p= \\
\text { 0.0002) } \\
\text { O Tiotropium } 5 \mu \mathrm{g} \text { vs placebo, } 4.1 \% \text { ( } p= \\
0.6895 \text { ) }\end{array}$ & $\begin{array}{l}57.9 \% \text { vs } \\
64.5 \% \text { vs } \\
67.1 \% \text { vs } \\
61.3 \%\end{array}$ & $\begin{array}{l}\text { In patients taking part in a self- } \\
\text { management behavior-modification pro- } \\
\text { gram, tiotropium+olodaterol improved } \\
\text { exercise endurance time compared with } \\
\text { placebo }\end{array}$ \\
\hline $\begin{array}{l}\text { Calverley } \\
2018[102]\end{array}$ & 7880 & $\begin{array}{l}\text { - Tiotropium+olodaterol } \\
5 / 5 \mu \mathrm{g} \mathrm{QD} \\
\text { - Tiotropium } 5 \mu \mathrm{g} \mathrm{QD}\end{array}$ & $\begin{array}{l}\text { - Rate of moderate and severe COPD } \\
\text { exacerbations: } \\
0.90 \text { vs } 0.97 \text { (rate ratio, } 0.93 ; p=0.0498 \text { ) }\end{array}$ & $74 \%$ vs $75 \%$ & $\begin{array}{l}\text { Tiotropium+olodaterol reduced } \\
\text { exacerbation rate compared with } \\
\text { tiotropium, but not to a significant } \\
\text { extent }\end{array}$ \\
\hline
\end{tabular}

$\overline{A U C_{0-24}}$ area under the curve from 0 to $24 \mathrm{~h}$ post-dose, $A U C_{0-12}$ area under the curve from 0 to $12 \mathrm{~h}$ post-dose, $A U C_{0-3}$ area under the curve from 0 to $3 \mathrm{~h}$ postdose, $B I D$ twice a day, COPD chronic obstructive pulmonary disease, ExT exercise training, FEV , forced expiratory volume in $1 \mathrm{~s}, H R Q o L$ health-related quality of life, $Q D$ once daily, QoL quality of life, SGRQ St. George's Respiratory Questionnaire

Moreover, two doses of tiotropium-the marketed $5-\mu \mathrm{g}$ dose and a non-approved, unmarketed 10- $\mu \mathrm{g}$ dose-were included in the primary analysis [91, 93]. These and other factors provide a plausible explanation for the imbalances observed in the aforementioned meta-analyses. In TIOSPIR $^{\oplus}$, a similar impact on survival was observed between tiotropium Respimat $^{\oplus} 2.5 \mu \mathrm{g}$ and tiotropium HandiHaler ${ }^{\odot} 18 \mu \mathrm{g}$, which expands upon findings from UPLIFT and reinforces the safety and efficacy of tiotropium in patients with COPD, regardless of cardiac arrhythmia history [26, $29,81]$.

Lastly, results of an analysis of the tiotropium COPD clinical program (Table 2) showed that the characteristics of patients included in the RCTs were representative of "real-life" patient populations, thus demonstrating external validation of the results [94]. Further, tiotropium Respimat $^{\oplus} 2.5 \mu \mathrm{g}$ or $5 \mu \mathrm{g}$ had similar exacerbation efficacy and safety to that of tiotropium HandiHaler ${ }^{\circledR} 18 \mu \mathrm{g}$ [81].

\section{Clinical development of tiotropium/olodaterol Respimat ${ }^{\circledast}$}

As mentioned, the clinical development of tiotropium culminated with evidence supporting its use in a fixeddose combination with olodaterol. The ToVITO ${ }^{\circ}$ program, which involved more than 16,000 patients and is outside the scope of this review, was designed to evaluate the effect of tiotropium/olodaterol $(2.5 / 5 \mu \mathrm{g}$ and/or $5 / 5 \mu \mathrm{g})$ Respimat $^{\oplus}$ on various efficacy parameters, as well as its safety. Results of these trials, and others, demonstrated that tiotropium/olodaterol provided a significant, incremental benefit over tiotropium monotherapy in alleviating COPD symptoms such as breathlessness, improving lung function and QoL, and reducing moderate and severe exacerbations (Table 3) [95-102]. In the DYNAGITO $^{\circ}$ trial, tiotropium/olodaterol reduced the rate of moderate and severe exacerbations by $7 \%$ compared with tiotropium alone, which did not meet the predefined significance level of 0.01 . However, in a post 
hoc analysis using multiple covariate models similar to those used in the SPARK and FLAME trials, an 11\% reduction in moderate-to-severe exacerbations was observed [102, 103]. Results across trials included in the ToVITO $^{\circ}$ program showed no significant differences in the frequency of general and serious adverse events between tiotropium/olodaterol Respimat $^{\circ}$ and mono components [104].

Tiotropium will continue to be the first-line treatment for newly diagnosed COPD, in particular in mild to moderate cases and infrequent exacerbators. We hope that early diagnosis will be more frequent in the future and these newly diagnosed cases, probably with milder disease, might be optimal candidates for treatment with tiotropium/olodaterol if new studies demonstrate that optimal early bronchodilation results in improved longterm outcomes.

\section{Conclusions}

Treatment goals for COPD include reduction in symptoms and future risk of exacerbations $[1,2,105]$. Per GOLD recommendations, LAMA monotherapy is recommended as initial treatment for GOLD groups $\mathrm{B}, \mathrm{C}$, and D. LABA/LAMA combination therapy may be considered in group $B$ patients with severe breathlessness and is an initial treatment option for group D patients who are highly symptomatic [2]. No other LAMA has been proven superior to tiotropium, making it an optimal LAMA as monotherapy and as the backbone LAMA in LABA/LAMA combination therapy. In most comparative studies of tiotropium and placebo, ipratropium, or salmeterol, tiotropium provided significant beneficial effects on lung function, including improvements in $\mathrm{FEV}_{1}$ and FVC [21-36]. Tiotropium also significantly improved exacerbationrelated outcomes such as reduction in the number of exacerbations/PY, reduction in the proportion of patients experiencing $\geq 1$ exacerbation and exacerbationrelated hospitalizations, increase in the time to first exacerbation, and reduction in HCRU compared with placebo and salmeterol [22-24, 26, 28, 34, 36-39]. In addition, tiotropium treatment improved HRQoL and significantly reduced dyspnea, need for "as-needed" SABA use, and lung hyperinflation, resulting in improvement in exertional dyspnea and exercise endurance $[21-23,26,28,29,32,34-36,45,46]$. The longterm efficacy of tiotropium was demonstrated in the UPLIFT trial. Finally, tiotropium was comparable to ICS/LABA (fluticasone/salmeterol) in improving lung function and reducing exacerbations $[66,67]$ and had a greater effect on exacerbation rates than LABAs $[39,73]$. Because long-term use of ICS is associated with systemic and local side effects, tiotropium is a suitable alternative to ICS/LABA combinations.
Overall, tiotropium is safe and efficacious as a longterm, QD LAMA for the maintenance treatment of COPD and for reducing COPD exacerbations or for the maintenance treatment of COPD as part of longterm, QD, fixed-dose LAMA/LABA (tiotropium/olodaterol) $[6,7,9]$.

\section{Supplementary information}

Supplementary information accompanies this paper at https://doi.org/10. 1186/s12931-020-01407-y.

Additional file 1. Tiotropium in chronic obstructive pulmonary disease - a review of clinical development. An infographic that provides a summary of the clinical trial results of tiotropium in chronic obstructive pulmonary disease

\section{Abbreviations}

$\mathrm{AUC}_{0-24}$ : area under the curve for the 24-h period post-morning dose; BID: twice daily; Cl: confidence interval; COPD: chronic obstructive pulmonary disease; DPI: dry-powder inhaler; EU: European Union; FEV $_{1}$ : forced expiratory volume in $1 \mathrm{~s}$; FVC: forced vital capacity; GLOW: glycopyrronium bromide in COPD airways; GOLD: Global Initiative for Chronic Obstructive Lung Disease; HCRU: health care resource utilization; HR: hazard ratio; HRQOL: health-related quality of life; IC: inspiratory capacity; ICS: inhaled corticosteroid; INHANCE: INdacaterol to Help Achieve New COPD treatment Excellence; INSPIRE: Investigating New Standards for Prophylaxis in Reducing Exacerbations; INTENSITY: INdacaterol Towards Establishment of cliNical SuperiorITY study; INTIME: INdacaterol \& Tlotropium: Measuring Efficacy; INVIGORATE: Indacaterol: Providing Opportunity to Re-engage Patients with Life; LABA: long-acting $\beta_{2}$-agonist; LAMA: long-acting muscarinic antagonist; MISTRAL: Mesure de I'Influence de Spiriva ${ }^{\oplus}$ sur les Troubles Respiratoires Aigus à Long terme; OR: odds ratio; PEFR: peak expiratory flow rate; pMDI: pressurized metered-dose inhaler; POET-COPD: Prevention Of Exacerbations with Tiotropium in COPD; PY: patient-year; QD: once daily; QID: four times a day; RCT: randomized controlled trial; RR: rate ratio; SABA: short-acting $\beta_{2}$-agonist; SAMA: short-acting muscarinic antagonist; SGRQ: St. George's Respiratory Questionnaire; SMl: soft mist inhaler; TDI: transition dyspnea index; TIOSPIR: Tiotropium Safety and Performance In Respimat; TIPHON: Tiotropium: Influence sur la Perception de l'amélioration des activites Habituelles Objectivée par une echelle Numerique; UPLIFT: Understanding Potential Long-Term Impacts on Function with Tiotropium; US: United States

\section{Acknowledgements}

The authors meet the criteria for authorship as recommended by the International Committee of Medical Journal Editors (ICMJE). The authors received no direct compensation related to the development of the manuscript. Writing, editorial support, and formatting assistance was provided by Sudha Korwar, PhD, Suchita Nath-Sain, PhD, and Maribeth Bogush, PhD, of Cactus Life Sciences (part of Cactus Communications), which was contracted and funded by Boehringer Ingelheim Pharmaceuticals, Inc. (BIPI). BIPI was given the opportunity to review the manuscript for medical and scientific accuracy as well as intellectual property considerations.

\section{Authors' contributions}

Both authors discussed and agreed to the scope of the manuscript and contributed to the development of the manuscript at all stages. Both authors have read and approved the final manuscript.

\section{Funding}

Writing, editorial support, and formatting assistance was provided by Cactus Communications, which was contracted and funded by Boehringer Ingelheim Pharmaceuticals, Inc. (BIPI). BIPI was given the opportunity to review the manuscript for medical and scientific accuracy as well as intellectual property considerations.

Availability of data and materials Not applicable. 


\section{Ethics approval and consent to participate}

Not applicable.

\section{Consent for publication}

Not applicable.

\section{Competing interests}

AA has received consultant fees from Boehringer Ingelheim, AstraZeneca, GlaxoSmithKline, and Novartis.

MM has received speaker fees from AstraZeneca, Boehringer Ingelheim, Chiesi, Cipla, Menarini, Rovi, Bial, Sandoz, Zambon, CSL Behring, Grifols, and Novartis; consulting fees from AstraZeneca, Boehringer Ingelheim, Chiesi, GlaxoSmithKline, Bial, Gebro Pharma, Kamada, CSL Behring, Laboratorios Esteve, Ferrer, Mereo Biopharma, Verona Pharma, TEVA, pH Pharma, Novartis, Sanofi, and Grifols; and research grants from GlaxoSmithKline and Grifols.

\section{Author details}

'Internal Medicine, Pulmonary Disease, University of Texas Health, and South Texas Veterans Health Care System, San Antonio, TX, USA. ${ }^{2}$ Pneumology Department, Hospital Universitary Vall d'Hebron/Nall d'Hebron Research Institute (VHIR). CIBER de Enfermedades Respiratorias (CIBERES), Barcelona, Spain.

Received: 3 February 2020 Accepted: 26 May 2020

Published online: 29 July 2020

\section{References}

1. Vogelmeier CF, Criner GJ, Martínez FJ, Anzueto A, Barnes PJ, Bourbeau J, et al. Global strategy for the diagnosis, management, and prevention of chronic obstructive lung disease 2017 report: GOLD executive summary. Arch Bronconeumol. 2017;53:128-49.

2. Global Initiative for Chronic Obstructive Lung Disease (GOLD). Global strategy for the diagnosis, management, and prevention of chronic obstructive pulmonary disease (2020 report). https://goldcopd.org/. Accessed 3 Feb 2020.

3. Meurs H, Oenema TA, Kistemaker LE, Gosens R. A new perspective on muscarinic receptor antagonism in obstructive airways diseases. Curr Opin Pharmacol. 2013;13:316-23.

4. Disse B, Speck GA, Rominger KL, Witek TJ Jr, Hammer R. Tiotropium (Spiriva): mechanistical considerations and clinical profile in obstructive lung disease. Life Sci. 1999:64:457-64.

5. Panning CA, DeBisschop M. Tiotropium: an inhaled, long-acting anticholinergic drug for chronic obstructive pulmonary disease. Pharmacotherapy. 2003;23:183-9.

6. Spiriva ${ }^{\circledast}$ Handihaler $^{\circledast}$ (tiotropium bromide inhalation powder). Prescribing information 2018. Boehringer Ingelheim International GmbH. https://docs. boehringer-ingelheim.com/Prescribing\%20Information/PIs/Spiriva/Spiriva. pdf. Accessed 3 Feb 2020.

7. Spiriva ${ }^{\oplus}$ Respimat $^{\oplus}$ (tiotropium bromide inhalation spray). Prescribing information 2018. Boehringer Ingelheim International GmbH. https://docs. boehringer-ingelheim.com/Prescribing\%20Information/PIs/Spiriva\%2 ORespimat/spirivarespimat.pdf. Accessed 3 Feb 2020.

8. Malerba M, Foci V, Patrucco F, Pochetti P, Nardin M, Pelaia C, et al. Single Inhaler LABA/LAMA for COPD. Front Pharmacol. 2019:10:390.

9. Stiolto ${ }^{\oplus}$ Respimat $^{\oplus}$ (tiotropium bromide and olodaterol inhalation spray). Prescribing information 2018. Boehringer Ingelheim International GmbH. https://docs.boehringer-ingelheim.com/Prescribing\%20Information/PIs/ Stiolto\%20Respimat/stiolto.pdf. Accessed 3 Feb 2020

10. Spiolto ${ }^{\oplus}$ Respimat $^{\oplus}$ (tiotropium and olodaterol inhalation solution). Summary of Product Characteristics 2017. Boehringer Ingelheim International GmbH. https://www.spiolto.com/sites/default/files/Spiolto_ Respimat_SPC_Feb_2017.pdf. Accessed 3 Feb 2020.

11. Ibrahim M, Verma R, Garcia-Contreras L. Inhalation drug delivery devices: technology update. Med Devices (Auckl). 2015;8:131-9.

12. Mahler DA. Peak inspiratory flow rate as a criterion for dry powder inhaler use in chronic obstructive pulmonary disease. Ann Am Thorac Soc. 2017;14: 1103-7.

13. Vincken W, Levy ML, Scullion J, Usmani OS, Dekhuijzen PNR, Corrigan CJ. Spacer devices for inhaled therapy: why use them, and how? ERJ Open Res. 2018;4:00065-2018.
14. Anderson P. Use of Respimat soft mist inhaler in COPD patients. Int J Chron Obstruct Pulmon Dis. 2006:1:251-9.

15. Newman SP, Brown J, Steed KP, Reader SJ, Kladders H. Lung deposition of fenoterol and flunisolide delivered using a novel device for inhaled medicines: comparison of RESPIMAT with conventional metered-dose inhalers with and without spacer devices. Chest. 1998;113:957-63.

16. Brand $P$, Hederer B, Austen G, Dewberry H, Meyer T. Higher lung deposition with Respimat soft mist inhaler than HFA-MDI in COPD patients with poor technique. Int J Chron Obstruct Pulmon Dis. 2008:3:763-70.

17. Pitcairn G, Reader S, Pavia D, Newman S. Deposition of corticosteroid aerosol in the human lung by Respimat soft mist inhaler compared to deposition by metered dose inhaler or by Turbuhaler dry powder inhaler. J Aerosol Med. 2005;18:264-72.

18. Zierenberg B. Optimizing the in vitro performance of Respimat. J Aerosol Med. 1999:12(Suppl 1):S19-24.

19. Dalby R, Spallek M, Voshaar T. A review of the development of Respimat soft mist inhaler. Int J Pharm. 2004;283:1-9.

20. Hochrainer D, Hölz H, Kreher C, Scaffidi L, Spallek M, Wachtel H. Comparison of the aerosol velocity and spray duration of Respimat soft mist inhaler and pressurized metered dose inhalers. J Aerosol Med. 2005;18:273-82.

21. Casaburi R, Briggs D Jr, Donohue JF, Serby CW, Menjoge SS, Witek T Jr. The spirometric efficacy of once-daily dosing with tiotropium in stable COPD: a 13-week multicenter trial. The US Tiotropium Study Group. Chest. 2000;118: 1294-302.

22. Casaburi R, Mahler DA, Jones PW, Wanner A, San PG, ZuWallack RL, et al. A long-term evaluation of once-daily inhaled tiotropium in chronic obstructive pulmonary disease. Eur Respir J. 2002;19:217-24.

23. Tonnel $A B$, Perez $T$, Grosbois JM, Verkindre C, Bravo ML, Brun M, et al. Effect of tiotropium on health-related quality of life as a primary efficacy endpoint in COPD. Int J Chron Obstruct Pulmon Dis. 2008:3:301-10.

24. Dusser D, Bravo ML, lacono P. The effect of tiotropium on exacerbations and airflow in patients with COPD. Eur Respir J. 2006;27:547-55.

25. Zhou Y, Zhong NS, Li X, Chen S, Zheng J, Zhao D, et al. Tiotropium in early-stage chronic obstructive pulmonary disease. N Engl J Med. 2017; 377:923-35

26. Tashkin DP, Celli B, Senn S, Burkhart D, Kesten S, Menjoge S, et al. A 4-year trial of tiotropium in chronic obstructive pulmonary disease. N Engl J Med. 2008:359:1543-54

27. Voshaar T, Lapidus R, Maleki-Yazdi R, Timmer W, Rubin E, Lowe L, et al. A randomized study of tiotropium Respimat soft mist inhaler vs. ipratropium pMDI in COPD. Respir Med. 2008;102:32-41.

28. Bateman E, Singh D, Smith D, Disse B, Towse L, Massey D, et al. Efficacy and safety of tiotropium Respimat SMI in COPD in two 1-year randomized studies. Int J Chron Obstruct Pulmon Dis. 2010;5:197-208.

29. Bateman ED, Tashkin D, Siafakas N, Dahl R, Towse L, Massey D, et al. A oneyear trial of tiotropium Respimat plus usual therapy in COPD patients. Respir Med. 2010;104:1460-72

30. Caillaud D, Le Merre C, Martinat Y, Aguilaniu B, Pavia D. A dose-ranging study of tiotropium delivered via Respimat soft mist inhaler or HandiHaler in COPD patients. Int J Chron Obstruct Pulmon Dis. 2007;2:559-65.

31. Littner MR, Ilowite JS, Tashkin DP, Friedman M, Serby CW, Menjoge SS, et al. Long-acting bronchodilation with once-daily dosing of tiotropium (Spiriva) in stable chronic obstructive pulmonary disease. Am J Respir Crit Care Med. 2000;161:1136-42

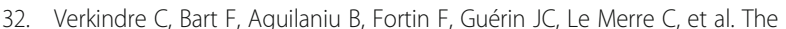
effect of tiotropium on hyperinflation and exercise capacity in chronic obstructive pulmonary disease. Respiration. 2006;73:420-7.

33. Chan CK, Maltais F, Sigouin C, Haddon JM, Ford GT. A randomized controlled trial to assess the efficacy of tiotropium in Canadian patients with chronic obstructive pulmonary disease. Can Respir J. 2007;14:465-72.

34. Vincken W, van Noord JA, Greefhorst AP, Bantje TA, Kesten S, Korducki L, et al. Improved health outcomes in patients with COPD during 1 yr's treatment with tiotropium. Eur Respir J. 2002;19:209-16.

35. Donohue JF, van Noord JA, Bateman ED, Langley SJ, Lee A, Witek TJ Jr, et al. A 6-month, placebo-controlled study comparing lung function and health status changes in COPD patients treated with tiotropium or salmeterol. Chest. 2002;122:47-55.

36. Brusasco V, Hodder R, Miravitlles M, Korducki L, Towse L, Kesten S. Health outcomes following treatment for six months with once daily tiotropium compared with twice daily salmeterol in patients with COPD. Thorax. 2003; 58:399-404. 
37. Niewoehner DE, Rice K, Cote C, Paulson D, Cooper JA Jr, Korducki L, et al. Prevention of exacerbations of chronic obstructive pulmonary disease with tiotropium, a once-daily inhaled anticholinergic bronchodilator: a randomized trial. Ann Intern Med. 2005;143:317-26.

38. Powrie DJ, Wilkinson TM, Donaldson GC, Jones P, Scrine K, Viel K, et al. Effect of tiotropium on sputum and serum inflammatory markers and exacerbations in COPD. Eur Respir J. 2007;30:472-8.

39. Vogelmeier C, Hederer B, Glaab T, Schmidt H, Rutten-van Mölken MP, Beeh $\mathrm{KM}$, et al. Tiotropium versus salmeterol for the prevention of exacerbations of COPD. N Engl J Med. 2011;364:1093-103.

40. van Noord JA, Bantje TA, Eland ME, Korducki L, Cornelissen PJ. A randomised controlled comparison of tiotropium and ipratropium in the treatment of chronic obstructive pulmonary disease. The Dutch Tiotropium Study Group. Thorax. 2000;55:289-94.

41. Drug approval package. Spiriva HandiHaler (tiotropium bromide monohydrate) inhalation powder. U.S. Food \& Drug Administration. https:// www.accessdata.fda.gov/drugsatfda_docs/nda/2009/021395Orig1s029.pdf. Accessed 3 Feb 2020.

42. Rice KL, Kunisaki KM, Niewoehner DE. Role of tiotropium in the treatment of COPD. Int J Chron Obstruct Pulmon Dis. 2007;2:95-105.

43. Anzueto A, Miravitlles M. Pathophysiology of dyspnea in COPD. Postgrad Med. 2017;129:366-74

44. Celli B, ZuWallack R, Wang S, Kesten S. Improvement in resting inspiratory capacity and hyperinflation with tiotropium in COPD patients with increased static lung volumes. Chest. 2003;124:1743-8.

45. O'Donnell DE, Flüge T, Gerken F, Hamilton A, Webb K, Aguilaniu B, et al. Effects of tiotropium on lung hyperinflation, dyspnoea and exercise tolerance in COPD. Eur Respir J. 2004;23:832-40.

46. Maltais F, Hamilton A, Marciniuk D, Hernandez P, Sciurba FC, Richter K, et al. Improvements in symptom-limited exercise performance over $8 \mathrm{~h}$ with once-daily tiotropium in patients with COPD. Chest. 2005;128: 1168-78.

47. Cooper CB, Celli BR, Jardim JR, Wise RA, Legg D, Guo J, et al. Treadmill endurance during 2-year treatment with tiotropium in patients with COPD: a randomized trial. Chest. 2013;144:490-7.

48. Seemungal TA, Hurst JR, Wedzicha JA. Exacerbation rate, health status and mortality in COPD--a review of potential interventions. Int J Chron Obstruct Pulmon Dis. 2009:4:203-23.

49. Wallace AE, Kaila S, Bayer V, Shaikh A, Shinde MU, Willey VJ, et al. Health care resource utilization and exacerbation rates in patients with $C O P D$ stratified by disease severity in a commercially insured population. J Manag Care Spec Pharm. 2019;25:205-17.

50. de Miguel-Diez J, Hernandez-Vazquez J, Lopez-de-Andres A, Alvaro-Meca A,

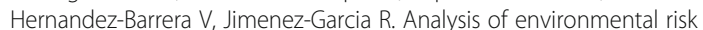
factors for chronic obstructive pulmonary disease exacerbation: a casecrossover study (2004-2013). PLoS One. 2019;14:e0217143.

51. Farias R, Sedeno M, Beaucage D, Drouin I, Ouellet I, Joubert A, et al. Innovating the treatment of COPD exacerbations: a phone interactive telesystem to increase COPD action plan adherence. BMJ Open Respir Res. 2019;6:e000379.

52. Anzueto A, Miravitlles M. Chronic obstructive pulmonary disease exacerbations: a need for action. Am J Med. 2018;131:15-22.

53. Miravitlles M, Garcia-Polo C, Domenech A, Villegas G, Conget F, de la Roza C. Clinical outcomes and cost analysis of exacerbations in chronic obstructive pulmonary disease. Lung. 2013:191:523-30.

54. Wedzicha JA, Calverley PMA, Albert RK, Anzueto A, Criner GJ, Hurst JR, et al. Prevention of COPD exacerbations: a European Respiratory Society/ American Thoracic Society guideline. Eur Respir J. 2017;50:1602265.

55. Miravitlles M, Soler-Cataluña JJ, Calle M, Molina J, Almagro P, Quintano JA, et al. Spanish guidelines for Management of Chronic Obstructive Pulmonary Disease (GesEPOC) 2017. Pharmacological treatment of stable phase. Arch Bronconeumol. 2017;53:324-35.

56. Alcazar Navarrete B, Ancochea Bermudez J, Garcia-Rio F, Izquierdo Alonso $J$, Miravitlles M, Rodriguez Gonzalez-Moro JM, et al. Patients with chronic obstructive pulmonary disease exacerbations: recommendations for diagnosis. Treatment and Care Arch Bronconeumol. 2019;55:478-87.

57. Anzueto A, Miravitlles M. Efficacy of tiotropium in the prevention of exacerbations of COPD. Ther Adv Respir Dis. 2009;3:103-11.

58. Vogelmeier CF, Asijee GM, Kupas K, Beeh KM. Tiotropium and salmeterol in COPD patients at risk of exacerbations: a post hoc analysis from POETCOPD ${ }^{\oplus}$. Adv Ther. 2015;32:537-47.
59. Anzueto A, Tashkin D, Menjoge S, Kesten S. One-year analysis of longitudinal changes in spirometry in patients with COPD receiving tiotropium. Pulm Pharmacol Ther. 2005;18:75-81.

60. Decramer M, Celli B, Kesten S, Lystig T, Mehra S, Tashkin DP, et al. Effect of tiotropium on outcomes in patients with moderate chronic obstructive pulmonary disease (UPLIFT): a prespecified subgroup analysis of a randomised controlled trial. Lancet. 2009;374:1171-8.

61. Troosters T, Celli B, Lystig T, Kesten S, Mehra S, Tashkin DP, et al. Tiotropium as a first maintenance drug in COPD: secondary analysis of the UPLIFT trial. Eur Respir J. 2010;36:65-73.

62. Tashkin DP, Celli B, Kesten S, Lystig T, Mehra S, Decramer M. Long-term efficacy of tiotropium in relation to smoking status in the UPLIFT trial. Eur Respir J. 2010:35:287-94.

63. Tashkin D, Celli B, Kesten S, Lystig T, Decramer M. Effect of tiotropium in men and women with COPD: results of the 4-year UPLIFT trial. Respir Med. 2010;104:1495-504.

64. Tashkin DP, Celli BR, Decramer M, Lystig T, Liu D, Kesten S. Efficacy of tiotropium in COPD patients with FEV1 $\geq 60 \%$ participating in the UPLIFT trial. COPD. 2012;9:289-96.

65. Morjaria JB, Rigby A, Morice AH. Inhaled corticosteroid use and the risk of pneumonia and COPD exacerbations in the UPLIFT study. Lung. 2017;195: 281-8.

66. Bateman ED, van Dyk M, Sagriotis A. Comparable spirometric efficacy of tiotropium compared with salmeterol plus fluticasone in patients with COPD: a pilot study. Pulm Pharmacol Ther. 2008;21:20-5.

67. Wedzicha JA, Calverley PM, Seemungal TA, Hagan G, Ansari Z, Stockley RA, et al. The prevention of chronic obstructive pulmonary disease exacerbations by salmeterol/fluticasone propionate or tiotropium bromide. Am J Respir Crit Care Med. 2008;177:19-26.

68. Niewoehner DE, Lapidus R, Cote C, Sharafkhaneh A, Plautz M, Johnson P, et al. Therapeutic conversion of the combination of ipratropium and albuterol to tiotropium in patients with chronic obstructive pulmonary disease. Pulm Pharmacol Ther. 2009;22:587-92.

69. Griffin J, Lee S, Caiado M, Kesten S, Price D. Comparison of tiotropium bromide and combined ipratropium/salbutamol for the treatment of COPD: a UK general practice research database 12-month follow-up study. Prim Care Respir J. 2008;17:104-10.

70. Vogelmeier C, Ramos-Barbon D, Jack D, Piggott S, Owen R, Higgins M, et al. Indacaterol provides 24-hour bronchodilation in COPD: a placebo-controlled blinded comparison with tiotropium. Respir Res. 2010;11:135.

71. Buhl R, Dunn LJ, Disdier C, Lassen C, Amos C, Henley M, et al. Blinded 12week comparison of once-daily indacaterol and tiotropium in COPD. Eur Respir J. 2011;38:797-803.

72. Donohue JF, Fogarty C, Lötvall J, Mahler DA, Worth H, Yorgancioglu A, et al. Once-daily bronchodilators for chronic obstructive pulmonary disease: indacaterol versus tiotropium. Am J Respir Crit Care Med. 2010;182:155-62.

73. Decramer ML, Chapman KR, Dahl R, Frith P, Devouassoux G, Fritscher C, et al. Once-daily indacaterol versus tiotropium for patients with severe chronic obstructive pulmonary disease (INVIGORATE): a randomised, blinded, parallel-group study. Lancet Respir Med. 2013;1:524-33.

74. Beier J, Kirsten AM, Mróz R, Segarra R, Chuecos F, Caracta C, et al. Efficacy and safety of aclidinium bromide compared with placebo and tiotropium in patients with moderate-to-severe chronic obstructive pulmonary disease: results from a 6-week, randomized, controlled phase IIlb study. COPD. 2013; 10:511-22.

75. Chapman KR, Beeh KM, Beier J, Bateman ED, D'Urzo A, Nutbrown R, et al. A blinded evaluation of the efficacy and safety of glycopyrronium, a oncedaily long-acting muscarinic antagonist, versus tiotropium, in patients with COPD: the GLOW5 study. BMC Pulm Med. 2014;14:4

76. Dalby RN, Eicher J, Zierenberg B. Development of Respimat ${ }^{\circledR}$ Soft Mist Inhaler ${ }^{\mathrm{TM}}$ and its clinical utility in respiratory disorders. Med Devices (Auckl). 2011;4:145-55.

77. Wachtel H, Kattenbeck S, Dunne S, Disse B. The Respimat ${ }^{\oplus}$ development story: patient-centered innovation. Pulm Ther. 2017;3:19-30.

78. van Noord JA, Cornelissen PJ, Aumann JL, Platz J, Mueller A, Fogarty C. The efficacy of tiotropium administered via Respimat soft mist inhaler or HandiHaler in COPD patients. Respir Med. 2009:103:22-9.

79. Boehringer Ingelheim. Boehringer Ingelheim announces FDA approval of Spiriva ${ }^{\oplus}$ Respimat $^{\oplus}$ (tiotropium bromide) inhalation spray for the maintenance treatment of COPD. https://www.boehringer-ingelheim.us/ press-release/boehringer-ingelheim-announces-fda-approval-spirivarespimat-tiotropium-bromide. Accessed 3 Feb 2020. 
80. Rau-Berger H, Mitfessel H, Glaab T. Tiotropium Respimat ${ }^{\circledR}$ improves physical functioning in chronic obstructive pulmonary disease. Int J Chron Obstruct Pulmon Dis. 2010;5:367-73.

81. Wise RA, Anzueto A, Cotton D, Dahl R, Devins T, Disse B, et al. Tiotropium Respimat inhaler and the risk of death in COPD. N Engl J Med. 2013;369: 1491-501.

82. Anzueto A, Calverley PMA, Mueller A, Metzdorf N, Haensel M, Jardim JR, et al. Demographic characteristics and clinical outcomes in patients from Latin America versus the rest of the world: a TIOSPIR ${ }^{\oplus}$ post-hoc analysis. Arch Bronconeumol. 2018;54:140-8.

83. Anzueto A, Wise R, Calverley P, Dusser D, Tang W, Metzdorf N, et al. The tiotropium safety and performance in Respimat $^{\oplus}\left(\mathrm{TIOSPIR}^{\oplus}\right)$ trial: spirometry outcomes. Respir Res. 2015;16:107.

84. Calverley PM, Tetzlaff K, Dusser D, Wise RA, Mueller A, Metzdorf N, et al. Determinants of exacerbation risk in patients with COPD in the TIOSPIR study. Int J Chron Obstruct Pulmon Dis. 2017;12:3391-405.

85. Singh S, Loke YK, Enright PL, Furberg CD. Mortality associated with tiotropium mist inhaler in patients with chronic obstructive pulmonary disease: systematic review and meta-analysis of randomised controlled trials. BMJ. 2011;342:d3215

86. Dong YH, Lin HH, Shau WY, Wu YC, Chang CH, Lai MS. Comparative safety of inhaled medications in patients with chronic obstructive pulmonary disease: systematic review and mixed treatment comparison meta-analysis of randomised controlled trials. Thorax. 2013;68:48-56.

87. Karner C, Chong J, Poole P. Tiotropium versus placebo for chronic obstructive pulmonary disease. Cochrane Database Syst Rev. 2012:CD009285.

88. Bateman ED. Tiotropium Respimat increases the risk of mortality: con. Eur Respir J. 2013;42:590-3.

89. Barnes NC, Jones PW, Davis KJ. Safety of tiotropium through the Handihaler: why did meta-analyses and database studies appear to give a false alarm? Thorax. 2014;69:598-9.

90. Singh S, Loke YK, Enright PL, Furberg CD. Mortality associated with tiotropium mist inhaler in patients with chronic obstructive pulmonary disease: systematic review and meta-analysis of randomised controlled trials. Responses available from: https://www.bmj.com/content/342/bmj.d3215/ rapid-responses. BMJ. 2011;342:d3215.

91. Disse B, Metzdorf N, Martin A, Cerasoli F, Leimer I. Mortality associated with tiotropium mist inhaler? A critical appraisal of the authors' selection and use of previously communicated tiotropium Respimat data BMJ 2011;342:d3215.

92. Abrahams R, Moroni-Zentgraf $\mathrm{P}$, Ramsdell J, Schmidt H, Joseph E, Karpel J. Safety and efficacy of the once-daily anticholinergic BEA2180 compared with tiotropium in patients with COPD. Respir Med. 2013;107:854-62.

93. Andersen L, Høimark L, Nielsen LP. Respimat mist inhaler safety. BMJ (online). 2011;342:d3215.

94. Miravitlles M, Price D, Rabe KF, Schmidt H, Metzdorf N, Celli B. Comorbidities of patients in tiotropium clinical trials: comparison with observational studies of patients with chronic obstructive pulmonary disease. Int J Chron Obstruct Pulmon Dis. 2015;10:549-64.

95. Buhl R, Maltais F, Abrahams R, Bjermer L, Derom E, Ferguson G, et al. Tiotropium and olodaterol fixed-dose combination versus monocomponents in COPD (GOLD 2-4). Eur Respir J. 2015;45:969-79.

96. Beeh KM, Westerman J, Kirsten AM, Hebert J, Grönke L, Hamilton A, et al. The 24-h lung-function profile of once-daily tiotropium and olodaterol fixed-dose combination in chronic obstructive pulmonary disease. Pulm Pharmacol Ther. 2015:32:53-9.

97. O'Donnell DE, Casaburi R, Frith P, Kirsten A, De Sousa D, Hamilton A, et al. Effects of combined tiotropium/olodaterol on inspiratory capacity and exercise endurance in COPD. Eur Respir J. 2017:49:1601348.

98. Maltais F, O'Donnell D, Gáldiz Iturri JB, Kirsten AM, Singh D, Hamilton A, et al. Effect of 12 weeks of once-daily tiotropium/olodaterol on exercise endurance during constant work-rate cycling and endurance shuttle walking in chronic obstructive pulmonary disease. Ther Adv Respir Dis 2018;12:1753465818755091.

99. Singh D, Ferguson GT, Bolitschek J, Grönke L, Hallmann C, Bennett N, et al. Tiotropium + olodaterol shows clinically meaningful improvements in quality of life. Respir Med. 2015;109:1312-9.

100. Beeh KM, Derom E, Echave-Sustaeta J, Grönke L, Hamilton A, Zhai D, et al. The lung function profile of once-daily tiotropium and olodaterol via Respimat ${ }^{\oplus}$ is superior to that of twice-daily salmeterol and fluticasone propionate via Accuhaler ${ }^{\circledR}$ (ENERGITO ${ }^{\oplus}$ study). Int J Chron Obstruct Pulmon Dis. 2016;11:193-205.
101. Troosters T, Maltais F, Leidy N, Lavoie KL, Sedeno M, Janssens W, et al. Effect of bronchodilation, exercise training, and behavior modification on symptoms and physical activity in chronic obstructive pulmonary disease. Am J Respir Crit Care Med. 2018;198:1021-32.

102. Calverley PMA, Anzueto AR, Carter K, Grönke L, Hallmann C, Jenkins C, et al. Tiotropium and olodaterol in the prevention of chronic obstructive pulmonary disease exacerbations (DYNAGITO): a double-blind, randomised, parallel-group, active-controlled trial. Lancet Respir Med. 2018;6:337-44.

103. Suissa S. Improving the efficiency of randomized trials: the DYNAGITO example. COPD. 2020;17:4-6.

104. Miravitlles M, Urrutia G, Mathioudakis AG, Ancochea J. Efficacy and safety of tiotropium and olodaterol in COPD: a systematic review and meta-analysis. Respir Res. 2017;18:196.

105. Singh D, Agusti A, Anzueto A, Barnes PJ, Bourbeau J, Celli BR, et al. Global strategy for the diagnosis, management, and prevention of chronic obstructive lung disease: the GOLD science committee report 2019. Eur Respir J. 2019;53:1900164.

\section{Publisher's Note}

Springer Nature remains neutral with regard to jurisdictional claims in published maps and institutional affiliations.

\section{Ready to submit your research? Choose BMC and benefit from:}

- fast, convenient online submission

- thorough peer review by experienced researchers in your field

- rapid publication on acceptance

- support for research data, including large and complex data types

- gold Open Access which fosters wider collaboration and increased citations

- maximum visibility for your research: over $100 \mathrm{M}$ website views per year

At BMC, research is always in progress.

Learn more biomedcentral.com/submissions 